\title{
THE CONSTITUTION OF EMPIRE: THE CASE FOR THE COLONISTS
}

\author{
Barbara A. Blacki \\ I. INTRODUCTION
}

[C]ommon lawyers have little or no sense of time. When John Hampden was prosecuted in 1636 for not paying the taxation called ship-money, both sides saw nothing incongruous in citing evidence from the reign of King Egbert, 802-39. So they selected evidence to agree with their tendentious assumptions. ${ }^{1}$

Let us suppose that in 1776 agreement had been reached between Britain and America on the proposition that the British Parliament had no authority over the colonies. Would twentieth-century scholarship see this as then-revolutionary doctrine? Would we say of it, as Maitland has of the Glorious Revolution, "[W]e must treat the Revolution as a revolution. ... We cannot work it into our constitutional law"?2 Let us suppose, further, that twentieth-century scholarship is virtually unanimous in holding that the Americans, who made that claim but failed to gain assent to it, were "wrong on the law." Does that answer our first question? Were they so wrong, or so clearly wrong, that we should today have recognized the revolutionary nature of the claim even if it had been assented to, and abided by, from that day to this? If we suggest that in those circumstances we could and would work the doctrine of colonial immunity from parliamentary authority into "our" constitutional law, are we simply refusing to call a Revolution a revolution? Periodically the historical imagination is captured by this problem (though not always stated in precisely these terms) and a flurry of scholarly activity ensues. Tendentious assumptions speed to and fro; there is no umpire and the game goes on until called on account

$\dagger$ Lecturer in History, Yale University. B.A. 1953, Brooklyn College; LL.B. 1955, Columbia University; M.Phil. 1970, Ph.D. 1975, Yale University. Member, New York and Connecticut Bars.

${ }^{1}$ G. Sayles, The King's Parliament of England 7 (1974).

2 F. Maitland, The Constitutional, History of England 285 (1965 ed.). 
of sheer exhaustion. This year of all years we may be forgiven if we take it up yet one more time. This year of all years, indeed, we may even be forgiven our tendentious assumptions. ${ }^{3}$

\section{The Historians}

\section{A. The McIlwain-Schuyler Debate}

In 1923 Charles H. McIlwain published The American Revolution: $A$ Constitutional Interpretation. ${ }^{4}$ The "main conclusion" of this extraordinary little book is, McIlwain tells us, "that the central problem of the American Revolution was the true constitution of the Empire." Today's reader, having had the benefit of the scholarship of the last half-century, may wonder why we should be particularly mindful of that familiar proposition; it is the case, however, that McIlwain's assertion and able support of this conclusion won him the gratitude of such scholars as Andrew McLaughlin, who wrote, "At last some one has done what ought to have been done long ago, and he has done it with learning and skill." 6 "For McLaughlin and others similarly minded, the accomplishment was largely in the demonstration that the economic historians "have read themselves out of court, if they came before the tribunal to establish the economic character of the whole movement." " Social and economic studies, wrote R. G. Adams, however excellent, "have unfortunately led us somewhat astray from the real point. Dr. Mcllwain's book brings us up sharply ...."

In support of his "main conclusion," Mcllwain announced to a startled world that the American colonists were more probably right than wrong in their claim that the British Parliament had

${ }^{3} \mathrm{I}$ have found student interest in this problem high, and I have benefited by the ideas and analyses that have been profferred in class discussion and in a number of interesting papers; for example, those of $\mathrm{C}$. Lee, The Conquest Doctrine: The English View from Coke to Mansfield, April, 1975 (unpublished paper on file with the author) and B. Miller, The British Constitution and the American Revolution: A Reassessment of the McIlwain-Schuyler Debate; Maryland as a Test Case, January 9, 1975 (unpublished essay on file at Yale Univ. History Dep't).

${ }^{4}$ C. Mcillwain, The American Revolution: A Constimutional Interpretation (1923).

${ }^{5} I d$. ix-x.

${ }^{6}$ McLaughlin, Book Review, 18 Am. Pol. Scr. Rev. 180 (1924).

${ }^{7} I d .182$.

${ }^{8}$ Adams, Book Review, 22 Mich. L. Rev. 505, 506 (1924). McLaughlin and Adams had in mind the work of such scholars as Arthur Schlesinger, Sr. and J. Franklin Jameson. See also Stock, Book Review, 18 Am. J. INT'L L. 654 (1924). 
no authority over the colonies. ${ }^{9}$ The dominions, they said, were the king's dominions; the king, they said, was their link-and their only link-with empire; Parliament, they said, had naught to do with them. And Mcllwain's splendidly idiosyncratic view was that "the balance of probability" inclined just that way. ${ }^{10}$ Moreover, it was McIlwain's belief that "[o]f all the arguments urged by the Americans, one alone supports the whole of their claim to a right of exemption from parliamentary interference, the argument drawn from the constitutional relation of realm and dominion." 11 The consequence of this assumption was the reduction of all arguments drawn from charters, or natural law, or fundamental law of any variety, to relative insignificance; for, said McIlwain, however persuasive such arguments might be on the issue of immunity from parliamentary taxation, they could not support total immunity. Nor were they necessary.

The case for the colonists as put by McIlwain regarded the Interregnum as a watershed and assumed that satisfactory establishment of the case for parliamentary authority must root such authority in the pre-Commonwealth constitution; for the question was the state of the imperial constitution at the time of the founding of the colonies. Any later importation of constitutional principles or theories would have no validity unless it could be shown that the colonists had acquiesced in them. Recognizing the claim that the true basis of parliamentary authority was the parliamentary supremacy attained in the Glorious Revolution and consolidated thenceforth, Mcllwain searched for what he assumed to be the necessary proof of American acquiescence in this supremacy and found none to satisfy him. Thus he could, and did, turn back to the ancient constitution, and he concluded "that the exercise of parliamentary authority . . . before the period of the Interregnum is not definitely and conclusively established, and that the exercise of such an authority afterward may therefore not unreasonably be regarded as without sufficient historical justification and henceforth 'unconstitutional' and 'illegal.' "12

We have had no shortage of naysayers to this proposition

${ }^{9}$ C. Mcllwain, supra note 4 , at 196-98.

${ }^{10} I d .78$.

${ }^{11}$ Id. 148.

${ }^{12}$ Id. 86. The context here was actually the Channel Islands, but, as McIlwain said, this was the very claim made by the Americans. I have used this quotation because it states McIlwain's conclusion with admirable precision. 
nor any insufficiency of grounds for dissent therefrom-since 1929. But immediate reaction was, on the whole, favorable, as one may gather from the fact that Professor McIlwain was awarded a Pulitzer Prize for his efforts. And we find reviewers asserting that McIlwain had at least "so far proved his case that it is no longer possible to say that 'the colonists would have lost their case if the decision had turned upon an impartial consideration of the legal principles involved," "13 and that he had demonstrated "the absurdity of sweeping aside ... the whole colonial claim as 'absurd." "14 There was some published dissent, certainly, even from this decidedly cautious position, but not (to my knowledge) from McIlwain's picture of the pre-Interregnum constitution. The occasional rejection of Mcllwain's thesis was not by way of rebuttal of his case to 1649 , but by characterization of that case as irrelevant given the Glorious Revolution, the parliamentary supremacy established thereby, and the colonists' alleged acceptance of the new order. ${ }^{15}$ As to the pre-1649 case, the consensus probably was that McIlwain "is on indisputable ground certainly as regards the situation down to the Givil War and the establishment of the Commonwealth."16 But nothing lasts forever, and 1929 brought Robert Schuyler's Parliament and the British Empire. ${ }^{17}$

Schuyler proposed to "test the validity of McIlwain's thesis, to determine, if possible, whether he should be acclaimed as an Athanasius contra mundum or cast into outer darkness as a belated heretic. In either case," Schuyler continued, "we shall not be ungrateful to him for showing that the historical antecedents of constitutional relations within the British Empire deserve further consideration." 18 It requires something less than razorkeen perception to see that these words, however graceful, are rhetorically inspired and would not have been written before the issue was decided in favor of casting McIlwain into outer darkness. We all know which alternative we shall find Schuyler to

13 Adams, Book Review, 33 Yale L.J. 567, 568 (1924). The inner quotation is from A. SChlesinger, New Viewpoints in American History 179 (1922).

${ }^{14}$ McLaughlin, supra note 6, at 181 . The inner quotation is from S. Fisher, THE Struggle fOR AMERICAN INDEPENDENCE 202-03 (1908). See also C. McIlwain, supra note 4 , at $91,197$.

${ }^{15}$ See, e.g., Corwin, Book Review, 29 Am. Hist. Rev. 775 (1924). Cf. Myers, Book Review, 11 A.B.A.J. 98 (1925).

${ }^{16}$ Stock, supra note 8 , at 654 .

17 R. Schuyler, Parliament aNd the British Empire (1929).

${ }^{18} I d .2$. 
have opted for in the end. And so we do. McIlwain's thesis was reduced (or so Schuyler evidently believed) to rubble, and however grateful we were instructed to be to Mcllwain for whatever fringe benefits we could derive from his efforts, out he went. And, unlike those who had come before, Schuyler challenged Mcllwain on McIlwain's own ground. The McIlwain thesis as to the pre-Interregnum constitution was rejected, not for irrelevance in the face of growing parliamentary supremacy, but on the shattering ground of inaccuracy. We must follow the arguments with some care to ascertain just what it was that Schuyler may fairly be said to have proved and, therefore, to have disproved.

On January 30, 1649, Charles I was executed. On May 19, 1649, "Parliament" enacted

That the People of England, and of all the Dominions and Territories thereunto belonging, are and shall be, and are hereby Constituted, Made, Established, and Confirmed to be a Commonwealth and Free-State; And shall from henceforth be Governed as a Commonwealth and Free-State, by the Supreme Authority of this Nation, The Representatives of the People in Parliament, and by such as they shall appoint and constitute as Officers and Ministers under them for the good of the People, and that without any King or House of Lords. ${ }^{19}$

This, said McIlwain, was the first expression of "that disastrous political subordination to the Englishmen of 'this Nation' and to the 'Supreme Authority' of their parliament, of all other Englishmen outside the realm in the other dominions formerly belonging to the King." Commonwealth Parliament had barely an alternative; there was no king, and Parliament thus had to lay claim to the king's dominions or watch them go their way. ${ }^{21}$ But if the claim was inevitable, it was not necessarily constitutionally valid either as an application of existing principles or as the foundation for later claims.

Schuyler at first seems to be in agreement with McIlwain on

192 Acts and Ordinances of the InterRegnum 122 (C. Firth \& R. Rait eds. 1972).

${ }^{20}$ C. McIllwain, supra note 4, at 22.

${ }^{21} I d .26$. 
the Act of 1649 and, by implication, the prior constitutional position:

This was a formal announcement of a tremendous innovation, for which no precedent can be found before 1649. When in earlier times the dominions were mentioned in English statutes they were referred to as dominions of the King, or as dominions of the realm, but since the realm itself was spoken of as one of the King's dominions, the variation in phraseology was evidently not intended to indicate any difference in meaning. There was certainly no implication that the dominions belonged to those subjects of the King who happened to reside in England. ${ }^{22}$

Thus far the match bids fair to degenerate into a love-feast. But Schuyler next inquires whether the legislation of the Long Parliament "laid the foundation of parliamentary legislation for the dominions. If so, it would have to be conceded that the legal doctrine of the imperial sovereignty of the British Parliament, which is accepted today by all lawyers and judges throughout the British Empire, was conceived in iniquity." 23 Thus the admission that the Act of 1649 announced a "tremendous innovation" is not the admission that the Act "laid the foundation of parliamentary legislation for the dominions." Moreover, if it did, then even though the doctrine of parliamentary authority over the dominions was conceived in iniquity, it was not necessarily unconstitutional. Schuyler, in fact, never faces the issue of the legal consequences, if any, of iniquitous conception-nor does he have to, ${ }^{24}$ for he is convinced that the Act of 1649 did not lay any foundations whatever, and thus the question does not arise.

\section{B. Evaluation}

Mcllwain, it must be said, clearly overdrew his argument and in fact argued himself (as well as the economic historians)

\footnotetext{
${ }^{22}$ R. SCHUYLER, supra note 17 , at 7 .

${ }^{23}$ Id. 8 (emphasis supplied) (footnote omitted).

${ }^{24}$ Nor can we be entirely certain what Schuyler meant by "iniquity." All "legislation" from 1642 to 1660 was revolutionary and, since this was a revolution that came unstuck, is now held never to have had de jure existence. If the iniquity lies in the revolutionary character of the Act introducing the doctrine rather than in its failure, we must suppose Schuyler would have believed, with McIlwain, that American assent to the consequences of the Glorious Revolution in 1689 was essential, at least to prevent iniquity. But perhaps not essential to constitutionality?
} 
out of court. As we have seen, he claimed that the exercise of parliamentary authority before the Interregnum had not been "definitely and conclusively established." Exercise, then, was the test, and McIlwain's words were, naturally enough, simply a challenge to scholars to go out and search the records in an effort to establish "definitely and conclusively" that parliamentary authority was exercised before the Interregnum. And that they have done. Schulyer was only the first; his success may be measured by the unmeasured language of Julius Goebel's review:

The bones of that ancient controversy which was settled by force of arms in America, some 150 years ago, were recently disinterred by Professor McIlwain, in his book, The American Revolution, which, at this late date, would probably have -created but little public stir, had not the work been distinguished by the bestowal of the Pulitzer Prize. This circumstance will, no doubt, exert some influence upon the future currency of Mcllwain's views, and the scholars or specialists who may become acquainted with Professor Schuyler's effective demolition of the very core of McIlwain's work will be unable to prevent the perpetuation of one more myth of popular historiography. Schuyler's work is no mere coup de fleuret, it is as stunning a scholarly blow as one could imagine.

Briefly stated, Parliament and the British Empire presents the picture of Parliament legislating for the king's dominions with satisfying pertinacity from the fourteenth century onward. As the tale of statute after statute is told, one wonders how any historian could ever have entertained a contrary view. ${ }^{25}$

Thus spake Goebel, and his reaction, except in its elegance of expression, is typical; the closest thing I have seen to an unfavorable review of Schuyler is one in which he is berated for laboring the obvious. ${ }^{26}$ Goebel, noted in equal parts for his brilliance, learning, and acerbity, was not even, this time, by very much the most contemptuous. ${ }^{27}$ Not that all who commented took obvious delight in crushing Mcllwain; some were gentle,

${ }^{25}$ Goebel, Book Review, 30 Colum. L. Rev. 273 (1930).

${ }^{26}$ Corbett, Book Review, 18 Calif. L. Rev. 342 (1930).

${ }^{27}$ See, e.g., id. 343: "[Schuyler's] contribution to political thought is slight. It is, however, quite sufficient to dispose of Professor Mcllwain's contention ...." 
but after 1929 none were prepared to say that Parliament had not legislated for the dominions before the Interregnum. ${ }^{28}$

Moreover, if Parliament had always legislated for the dominions, the legal issue as a whole seems closed; the colonists' case as stated by McIlwain was, after all, based on the theory that the practice was ushered in during the Interregnum by the Commonwealth Act. If it was not, then a legal case would perforce have to rest either on the theory that the exercise had always been illegal, or on the theory that though once legal, it had in some way become illegal. The former was, in truth, absurd, and nobody argued the latter. As McIlwain said in 1940, "[M]ost recent American historians of our Revolution have apparently refused to follow me in an inclination-which, nevertheless, I still feel-to prefer the contention of Camden and the Americans, even on its strictly legal side, to that of Northington and Mansfield."29 That, I believe, holds for 1976 as for 1940, though we have had reactions short of total disavowal of his position. ${ }^{30}$ We have had, for example, those who say "who knows?"31 and those who say "who cares?"32 The difference between them is that the first group tends to think the matter worth consideration, if unanswerable, while the second thinks it a waste of time. In-but not precisely of-the latter group is Charles M. Andrews. Too much the scholar to indulge a concept of irrelevance in the air, so to speak, Andrews did think the legal issue contextually irrelevant:

The American intellectuals may have been legally right, as Professor McIlwain contends, in thus denying the validity of a parliamentary statute to bind the col-

${ }^{28}$ See Barnes, Book Review, 40 Y ALE L.J. 156 (1930); Heaton, Book Review, 14 Mins. L. Rev. 833 (1930); Wrong, Book Review, 23 AM. Pol. Scr. Rev. 1011 (1929); Book Review, 28 Mich. L. Rev. 633 (1930). Barnes, supra at 157, does say that although Schuyler's is "a most convincing case," it is impossible to make a final decision.

${ }^{29}$ C. Mcillwain, Constitutionalism: Ancient and Modern 8 (rev. ed. 1947). As to the contention of Northington and Mansfield, see note 49 infra \& accompanying text.

${ }^{30}$ That is, his position on the merits. On his point that the constitutional issue was uppermost, we have much agreement. See, e.g., D. Boorstin, The Genius of American Politics (1953).

${ }^{31}$ See, e.g., 1 B. Bailyn, Pamphlets of the American Revolution 709 (1965). Bailyn accepts the conclusion of Harvey Wheeler that the colonists were "asking constitutionalist questions of a 'pre-constitutional' society." See notes 45-46 infra.

${ }^{32}$ Even Randolph Adams, an early and enthusiastic supporter of American aims and ideals, said, "It makes little difference now whether John Adams was right or wrong." R. Adams, Political Ideas of the American Revolution 125 (3d ed. 1958). For a discussion of John Adams' position, see text accompanying notes 129-38 infra. 
onies, but they did not find it out till the question of taxation was reached and the menace of parliamentary aggression had begun to warn them of dangers to come. The "rightness" or "wrongness" of the matter, though of great significance in the history of opinion touching the organization of the British Empire, has but an academic interest in its relation to the progress of our revolution. The colonists would have gone ahead with their revolt, whatever the conclusions of the intellectuals might be, for the impulses behind that movement did not originate in the question of parliamentary right. ${ }^{33}$

And finally we have had studied silence-whether a sign of disdain or diffidence it is hard to say. The former is, alas, too commonly the outcome of historians' encounter with law. With the latter one would have to feel entire sympathy in the light of such expert intimidation as that practiced by Professor Goebel. Historians, of course, are a dauntless crew. But it would be no more than human to have a qualm or two about joining the ranks of perpetrators of myths of popular historiographyactually risking denial of the status of scholar or specialist-on the cool assumption that the scholar or specialist can come to one conclusion only, particularly when it seems clear that we do in truth have to do with myth. But it is important that we take care to establish exactly what the myth is, and how McIlwain came to perpetrate it.

Goebel expresses wonderment, as the tale of statute after statute unrolls, that any scholar could ever have thought otherwise. Truly it is a cause for wonderment, or would be if we knew of any scholar who had thought otherwise. Certainly the one Goebel had in mind did not "entertain a contrary view." McIlwain, although not familiar with the whole tale of statute after statute, was certainly not unaware of the existence of parliamentary legislation for the dominions long before 1649. Indeed, his approach ensured that he know a good bit of it; for he searched the record of constitutional relations within the British Empire, and in so doing he turned to Ireland as the closest constitutional parallel to the American colonies. In the course of investigating the relations between Ireland and the British Parliament, it must become clear that Parliament had indeed acted, for this one

33 C. Andrews, The Colonial Background to the American Revolution 62-63 (1924). 
dominion at least, from earliest days. ${ }^{34}$

How then could Mcllwain have denied the "exercise" of parliamentary authority for the dominions-and Ireland in particular-before the Interregnum? The answer is only in part that he did not know the extent of the exercise, but it is that in part. McIlwain did not pretend that his researches had been exhaustive (or therefore that his conclusions were more than tentative); nor, in his day, did he have the benefit of the research (published and unpublished) since concluded by scholars in America, Britain, and Ireland-some of it stimulated by his "little gem" of a book. ${ }^{35}$ One can dismiss what seems to be only an occasional exercise of parliamentary authority as aberrational, not substantially probative, and the like, much more easily than one can a massive body of legislation. Similarly one can put the burden of proving lawfulness on the side of the advocates of parliamentary authority if the exercise appears to be only occasional. And then, there were fair reasons-more than plausible, and in some cases certainly valid-for dismissing as immaterial some of the legislation which Mcllwain knew to be on the books. For example, one of the claims of Irishmen such as Molyneux who denied the authority of the English Parliament over Ireland was that only statutes declaratory of the common law were in force in Ireland, proprio ingore, without some act of the Irish Parliament. ${ }^{36}$ Now that is an appealing argument to such a scholar as McIlwain; it might have been made to persuade him.

${ }^{34} \mathrm{Cf}$. C. McIlwain, supra note 4, at 25 . McIlwain expressly recognized that "actual legislation for the dominions had occurred earlier" than 1641, although he dismissed the pre-1641 legislation as " $a$ few earlier and much less definite transactions between the English Parliament and other dominions of the Crown in the later Middle Ages and just after ...." Id. 27-28. Additionally, McIlwain quoted Governor Hutchinson's 1773 address to the Massachusetts assembly: "That acts of parliaments for several hundred years past, have respected countries, which are not strictly within the realm, you might easily have discovered by the statute books." Id. 126 .

${ }^{35}$ See, e.g., G. HaNd, ENGlish Law in IRELANd 1290-1324, at 159, 161-71 (1967); H. Richardson \& G. Sayles, The Irish Parliament in the Middle Ages 61-62, 244-68 (1952); A. Donaldson, The Application in Ireland of English and British Legislation Made Before 1801, May, 1952 (unpublished dissertation in Queen's University of Belfast); J. Juricek, English Claims in North America to 1660: A Study in Legal and Constitutional History (1970) (unpublished dissertation in University of Chicago); Goebel, Introduction to J. Smith, Appeals to the Privy Council from the AMerican Plantations xiii, xlix-lix (1950); Hand, English Lazw in Ireland 1172-1351, 23 N. IR. L.Q. 393, 399-400, 413, 416 (1972); Madden, 1066, 1776 and All That: The Relerance of English Medieval Experience of 'Empire' to Later Imperial Constitutional Issues, in PersPectives OF EMPIRE 9, 14-21 (J. Flint \& G. Williams eds. 1973).

${ }^{36}$ W. Molyneux, The Case of Ireland's Being Bound by Acts of Parlament in England Stated 38-78 (1968). 
For McIlwain believed strongly that law-declaring was a function of Parliament far later than the time when most scholars had (or have) seen it-indeed, to Tudor times as a matter of awareness rather than practice. ${ }^{37}$ In his discussion of this point he says: "The conscious distinction between acts declaratory of new law and acts in affirmance of old is one, then, that can be applied with entire safety for our purpose practically only to Tudor and post-Tudor enactments." ${ }^{38}$ Thus no application in Ireland of a pre-Tudor English statute can validly be used as proof of conscious application of a statute introductory of new law or, it follows, of any right on the part of the English Parliament to make new law for Ireland. ${ }^{39}$ So it happened that McIlwain's own theory of statutory development predisposed him to agreement, in part at least, with the Irish advocates of exemption from parliamentary authority. And we should note that this theory of statutory development illustrates his extreme sensitivity to the form of anachronism that consists of reading the past back into the more remote past-let us say, for example, interpreting the fourteenth century in the light of what we know of the sixteenth.

Schuyler, however, did not stop with a demonstration of the fact of legislation-the retrospect, as he called it-but went on to theory. And the theory seems, if anything, more shattering to the McIlwain thesis than the facts. First, Schuyler read Mcllwain a lesson in black-letter law and reminded him of things that, it would seem, no one approaching this topic should need to be reminded of. Parliment, he said, has never had legal existence apart from the king. An act of Parliament is an act of the king; it is an expression of the will of the king. It is doctrinal nonsense to speak of an act of Parliament in opposition to the king, for the king legislates through Parliament. ${ }^{40}$

Here we have a point so plainly incontrovertible-and horrifyingly elementary-that it carries, at first, more weight than it deserves. For it seems to slay with a stroke the argument that the king and not Parliament constitutes the link with empire. But the answer to it is, of course, that there is no conflict between the doctrine that the act of Parliament is an expression of the will of the king and a constitutional obligation on the part of the king to (1910).

${ }^{37}$ See C. McIllwain, The High Court of Parliament and Its Supremacy 109-229

${ }^{38}$ C. McIllwain, supra note 4 , at 74.

${ }^{39}$ See R. SCHUYLER, supra note 17 , at 55-59.

40 Id. 5-6, 23. 
veto a given bill. Or so George III believed! ${ }^{41}$ If he was wrong, it must be because the royal assent was no longer optional-there was no royal veto. ${ }^{42}$ If that was the case, it was a function of the parliamentary supremacy that grew out of the Glorious Revolution-a post-settlement development which, on McIlwain's assumptions (and ours for now, if not Lord Mansfield's) must be shown to have been acquiesced in by the colonists. Short of acquiescence (or naked might—which, in the event, proved an illusion) the colonists might well demand, as Jefferson did, ${ }^{43}$ that George III fulfill his constitutional obligation to keep Parliament out of dominion affairs. At least there is nothing about this position which is inconsistent with the doctrine that in legal contemplation an act of Parliament is an expression of the will of the king.

Schuyler then went back of modern legal theory to its medieval origins. Parliament, he reminded us, was originally no more than a name for a particular session of the king's council; it is in this conciliar role that the origins of parliamentary legislation for the dominions (and indeed the realm) will be found. The dominions were the king's dominions; it was given to the king to legislate for his dominions; the king might legislate for his dominions with his councillors indifferently, in Parliament or out. ${ }^{44}$ Thus we have the conciliar theory. Schuyler (so far as I know) was its first propounder; perhaps none today will question its soundness. Nevertheless, it was on this sound explanation that Schuyler ran into trouble with later commentators; for they have assumed that Schuyler was not only offering the conciliar theory in explanation of the beginnings of parliamentary competence in the dominions but was also suggesting that it justified such competence in the eighteenth century. It is by no means certain that Schuyler intended any such thing. Be that as it may, on that assumption at least two commentators ${ }^{45}$ have noted the inappro-

${ }^{41}$ Thus he considered whether he might not be obliged to withhold the royal assent from a bill which he believed inconsistent with the obligation of his coronation oath. See Letter from George III to Lord Kenyon, March 7, 1795, in THE LeTtERS of King George III 236-38 (B. Dobrée ed. 1935).

${ }^{42}$ The royal assent to a bill [The Scotch Militia Bill] was last withheld in 1707, by Anne. See AN Encyclopedia of Parliament 640 (N. Wilding \& P. Laundy eds. 1968).

${ }^{43}$ See T. Jefferson, A Summary View of the Rights of British America (1774), in 2 The Writings of ThOMAS JefFerson 49-89 (P. Ford ed. 1904).

${ }^{44} \mathrm{R}$. SCHUYLER, supra note 17 , at 34-39.

45 Madden, supra note 35; Wheeler, Calvin's Case (1608) and the Mcllwain-Schuyler Debate, 61 AM. HIST. Rev. 587 (1956). See also Heaton, supra note 28. 
priateness of such a justification, and we can see it readily enough. Do we really mean to suggest (the objection runs) that because a council bearing the name "parliament" might act in medieval times the representative assembly which bore the same name in the eighteenth century might act? Would not the appropriate heir to power (it might be added) be the functional rather than the nominal descendant of the original institution -that is, the Privy Council?

In neither case where this difficulty was alluded to did the writer think it satisfactory to assume that the powers of an institution will pass through the centuries to its nominal descendant, however altered the character and function of that institution. But, then again, in neither case did the writer suggest that the alterations in question had, in law, deprived the modern Parliament of the powers of the medieval parliament. One writer remains noncommittal; ${ }^{46}$ the other categorically takes the view that the legal position was not affected by this alteration in the nature of parliament. He has no doubt that "Schuyler's evidence is legally unanswerable"; but, he says, "What may be accepted by lawyers in advocating [?] a case need not necessarily convince historians." 47 (He is presumably not asserting here that a case may be legally sound for lawyers but not for historians.) "Historians," we are told, "cannot overlook the gulf between a period of royal dictatorship and one of embryonic cabinet government, or between one of fundamental law and one of parliamentary omnicompetence."48

Lawyers, then, not only can but do overlook such gulfs-we are little in touch with reality it would seem. Is that really the case? Do common lawyers truly have no sense of time? Perhaps, perhaps. But if we have no sense of time, do we not have a sense which will do as a substitute? Do we not have a maxim which tells us that when the reason for the rule disappears the rule no longer holds? We do indeed-and it was not violated in this case, even by the eighteenth-century jurists whose names are above all others associated with the doctrine of the legality of parliamen-

${ }^{46}$ Wheeler, supra note 45, at 597: "Both [Mcllwain and Schuyler] could find support but neither could find victory. It was a question which could not be resolved historiographically, for both men were asking a constitutionalist question of a 'pre-constitutional' society." The last phrase is quoted with approval in I B. BAILYN, supra note 31 , at 709.

${ }^{47}$ Madden, supra note 35, at 23.

${ }^{48} I d .24$. 
tary authority over the colonies. When we find Mansfield and Northington upholding that authority, we shall not find them basing it on Parliament's role as the king's council. ${ }^{49}$ If the rule in this case has not disappeared, it is not for failure to recognize that the original rationale has. It is because a new and, to Lords Mansfield and Northington, and to others, equally satisfactory rationale has taken its place, one not the least out of touch with reality as they saw it - until reality proved to be superior might in the Americans. While some found assent, and others swallowed the theory of virtual representation, and still others felt the need for no more satisfactory rationale than "because we say so," at least we hear nothing of a conciliar theory in the parliamentary debates of the eighteenth century.

On the other hand, an awareness of the conciliar origin of parliamentary authority is important. We must realize that, despite the virtual unanimity on the soundness of the British legal case, most historians today would agree that justice was on the side of the colonists. So McIlwain observed in $1940 ;^{\circ 0}$ and it remains true in 1976, through all the toils and turmoils of revisionism and hand in hand with the recent (and salutary) surge of interest in the perspective and plight of the loyalists. The conciliar origin underlines the injustice of the legally correct position. Furthermore, it is clear that what Goebel has happily called "the principle of constant encroachment"s1 is at work here. Despite disclaimers and substitute rationalia, medieval origins had an effect, and the authority of the eighteenth-century legislative assembly known as Parliament owes something to the authority of the twelfth-century council known as parliament.

We may (and must) clear McIlwain of the suspicion that he did not know either that in eighteenth- (and twentieth-) century British law an act of Parliament is an expression of the will of the king, or that Parliament was once the king's council. Neither, as we have seen, is a complete answer to the colonists' constitutional contention. As to the latter charge, it was put thus: "The wrath of Maitland was invoked, but this time against his famous disci-

${ }^{49}$ As Northington put it in the 1766 debate on the Conway Resolutions: "My lords, I seek for the liberty and constitution of this kingdom no farther back than the Revolution; there I make my stand." 16 Parliamentary History of England 164 (1966 ed.). For Mansfield's views, see id. 172-77.

5" C. McIllwarN, supra note 29 , at 8.

${ }^{51}$ Goebel, supra note 25, at lix. 
ple, McIlwain . . . .52 And Schuyler did indeed think it appropriate to repeat Maitland's famous injunction: "It is hard to think away out of our heads a history which has long lain in a remote past but which once lay in the future ...."53 The implication then is that if Mcllwain had not read the nature of the modern Parliament back into medieval times, he would have realized that Parliament, as the king's council, must always have legislated for the dominions. That can only bemuse the reader of McIlwain's book who gets as far as page sixty-four: "No single fault has been the source of so much bad history as the reading back of later and sharper distinctions into earlier periods where they have no place." 54 In fact, given all that we know of his work, and in the light of certain statements in The American Revolution, ${ }^{55} \mathrm{I}$ would suggest that this charge, as to McIlwain, is simply preposterous. It is far more believable that, knowing all about the gulf between medieval and modern, he assumed that the law took some notice of this-that if it goes without saying that Parliament's authority is rooted in its conciliar role, the law will recognize the inappropriateness of assuming that the authority descends to the nominal, rather than functional, descendant. Surely his failure to dwell on the conciliar role evidences a judgment of its irrelevance rather than ignorance or forgetfulness. When Mcllwain searched for the exercise of legislative authority, he searched for the exercise of legislative authority and, for that matter, of legislative authority. If he did not go back of the time when the institution in question was a legislature, it was not because he did not know that it had once been a council. McIlwain did on more than one occasion carry the remoter past forward into the remote past-it was, as Holdsworth noted, his great failing. ${ }^{56}$ But he never carried the remote past back into the remoter past. That he left to the Mansfields and their supporters, among them Holdsworth and, preeminently, A. B. Keith, whom Holdsworth credits (along with

52 Wheeler, supra note 45 , at 587 .

${ }^{53} \mathrm{~F}$. Schuyler, supra note 17 , at 34 , quoling F. Maitland, Introduction to Memoranda de Parliamento lxxxiii (1893).

${ }^{54}$ C. Mcllwain, supra note 4, at 64 .

55 For example, regarding Ireland Mcllwain cautioned: "Another cause of uncertainty is the undeveloped form of Parliament at the time of the earliest enactments in question, as well as the vagueness of our knowledge of the King's relation to it." $\mathrm{C}$. Mcllwain, supra note 4 , at 63 .

${ }^{56} 11$ W. Holdsworth, A History Of ENGLish LAW 123 (1938). 
Schuyler) with so completely answering Mcllwain that one need no longer dwell on the matter. ${ }^{57}$ But McIlwain was wrong, for all that. Parliament (in all its manifestations) had legislated for the king's dominions continuously from the beginning; that, when all is said and done, established a prima facie case of legal right, if not more. The burden of proof must be on the negative of the proposition, and it has not yet been shown that it could or can be met.

We must suspect that Professor McIlwain embarked on his inquiry in part because he was a whig, old-style. Plainly enough he was moved by his sense of the injustice of the British position-a sentiment, as remarked above, widely shared. Plainly enough he was moved as well by his inability (not, it seems, shared) to conceive that there can be something called "law," much less a constitution, which is an embodiment of injustice. It is hard for a man who defines "constitutionalism" as "limits"58 to see a constitution where there are no limits. To Tom Paine and others, then and now, the answer is, simply, that there is no constitution. ${ }^{59}$ McIlwain, like the colonists, resisted that conclusion. We may react to this by saying that it did credit to his heart but not his head, and that may be. I will say, however, that in my opinion it would be difficult to strike the balance of harm between the rule of heart over head and fear of the rule of heart over head. One gets more than a sense that in some quarters hard-headedness is all, and a discovery of the coincidence of historic truth with the desirable-of law with justice-rather shunned than otherwise. One hears the sigh of relief: "The Americans had justice on their side, but not law. $I$ am not a soft-headed fellow." At least McIlwain was an unabashed libertarian as well as a superb scholar. And if he was wrong (who is not at times?) his wrongness was not without a touch of rightness. For his demonstration of that touch of rightness to those who care to listen and learn, we are much in his debt.

Holdsworth tells us that it is too bad, really, that the controversy with the colonies was "cast into ... [a] legal mould"; the law was too easily seen to be on the side of arbitrary power (my phrase, not Holdsworth's, but accurate I think), and those who

\section{${ }^{57} \mathrm{Id}$.}

${ }^{58}$ C. Mcllwain, supra note 29, at 21-22.

59 Paine reached this conclusion after the American Revolution. See T. PaIne, Rights of Man 207-31 (H. Collins ed. 1969). See generally C. Mcllwain, supra note 29. 
could not think beyond the law thus dug in and lost an empire. ${ }^{60}$ How extraordinary that the twentieth-century British legal mind should regret recourse to law! Why not, rather, regret that the law was what it was, if it was truly of a nature which guaranteed disaster upon enforcement? The answer, of course, is in the "convention of the constitution." In their distribution of governmental power, the British have institutionalized the separation of the de facto from the de jure, and virtually enshrined that which the rest of us feel as an embarrassment-the unacceptable rule. The issue, as one government official put it recently, is not what Parliament cannot do (since Parliament can do anything), but what it cannot bring itself to do. Well then, when you do not live by law but by convention, you may take a cheerful view of the defects, not to say iniquities, of the law. Your mind then runs, not to reform of the law, but to ensuring that people will not insist upon it-will not cast controversy into a legal "mould." In such a system it is indeed too bad that men would decide, for a change, to live by law; what I find remarkable is that we are now so familiar with this system that we no longer see how extraordinary it is that we should find cause for lamentation in recourse to law. When this sort of thing happened in what legal historians are fond of calling matters of meum and teum, the English came up with equity. Equity, for all its nominal contrast with law, is a system of law. "But constitutional practice ... is not law ...."61

Perhaps the charm of this system is that it provides a continuing test of virtue-every time Parliament refrains from acting on the implications of omnipotence we have a victory for British self-restraint, a demonstration that Britons know how to behave without external compulsion. But once in a while, Britons, like everyone else (if not as often), do not know how to behave, and we can understand why the colonists, when building a nation, thought that a bit of external compulsion would the better ensure the blessings of liberty to themselves and their posterity. The modern British system was Burke's, ${ }^{62}$ and it led

6" 11 W. HoldsWORTH, supra note 56, at 124.

${ }^{61}$ Corbett, supra note 26 . See the splendid discussion of the law and practice of parliamentary sovereignty in J. Gough, Fundamental Law in ENGlish ConstituTIONAL. History 214 et seq. (rev. ed. 1961).

${ }^{62}$ See generally, e.g., E. BuRke, Reflections on the Revolution in France (1790), in E. Burke, Reflections on the Revolution in France 1, 12-33 (A. Grieve ed. 1967); E. Burke, A Letter from Mr. Burke to a Member of the National Assembly in 
straight to Mansfield; and we cannot wonder that the Americans turned from anything which led to Mansfield. But to whom, or to what, did they turn? Many believe that they turned to natural law, but Goebel tells us that they made their case "with solid shot from the magazine of common law precedent."63 To the extent that this is accurate, it was the common law of Edward Coke-of Bonham's Case ${ }^{64}$ in particular, and of Calvin's Case ${ }^{65}$

\section{The History: Royal Prerogative and Parliamentary Power in The Dominions}

\section{A. Edward Coke and Representatize Government}

American lawyers and historians are everlastingly being told that we read American legal development back into the opinions of Edward Coke. ${ }^{66}$ We have heard this so often that we have come to believe it; and we say, for example, that the colonists, in their interpretations of Calvin's Case and Bonham's Case, "reached conclusions that would have been alien to the thinking of the early seventeenth-century lawyers they quoted." 67 Or we say of James Otis:

Because he knew English history and the common law too well, because he clung too stubbornly to the veracity of the seventeenth-century notions of jurisprudence and parliamentary supremacy, he was eventually compelled to sacrifice Vattel for Coke, to deny natural reason for the sake of historical truth, and to miss the Revolution. ${ }^{68}$

Answer to Some Objections to His Book on French Affairs (1791), in id. 245-84. R. ADAMS, supra note 32 , at 54 , took a dim view of Burke's plea that attempts to define the imperial constitution cease; that is, his plea that the "legal mould" be avoided. Since this was essentially John Adams' position (though he, like Burke, spoke to the legal issues), it is interesting that R.G. Adams should so thoroughly have approved of John Adams while disapproving of Burke. In fact, it would appear that his disapproval of Burke's plea to put "the law" to one side reveals his disapproval of Burke's law. Contrast id. $\mathbf{5 4}$ with id. 121.

${ }^{63} \mathrm{~J}$. Goebel, The Oliver Wendell Holmes Devise History of the Supreme Court of the United States: Antecedents and Beginnings to 1801, at 95 (1973).

648 Co. Rep. 107, 77 Eng. Rep. 638 (K.B. 1607).

657 Co. Rep. 1a, 77 Eng. Rep. 377 (K.B. 1608).

${ }^{66}$ See, e.g., J. Gough, supra note 61, at 34, 32, 40 (the problem of Sir Edward Coke and fundamental law, including a review of much of the commentary on Bonham's Case). See also 2 Legal Papers of John Adams 177 et seq. (L.K. Wroth \& H. Zobel eds. 1965).

67 1 B. BaILYN, supra note 31 , at 709.

68 G. WoOd, The Creation of the American Republic: 1776-1787, at 9 (1969). 
The assumption usually seems to be that Coke's principles were more nearly realized in Britain than in America. That, to put it mildly, is not necessarily so. ${ }^{69}$ Coke certainly spoke to Englishmen, but by the eighteenth century these could be found on both sides of the Atlantic; it is time to consider anew the possibility that the Englishmen who heard him were the Englishmen in America. The colonists' case, as some of them sensed, took on life at the intersection of Calvin's Case and Bonham's Case. The hope of Bonham's Case we know:

And it appears in our books, that in many cases, the common law will controul Acts of Parliament, and sometimes adjudge them to be utterly void: for when an Act of Parliament is against common right and reason, or repugnant, or impossible to be performed, the common law will controul it, and adjudge such Act to be void .... .70

The promise of Calvin's Case is not, perhaps, as well understood, but it should be.

\section{Calvin's Case}

Caltin's Case was central to the contemporary debate over parliamentary power in the dominions and to the scholarly debate that we have been following. The case was contrived in an attempt to make some headway on the divisive and explosive issue of union between Scotland and England. ${ }^{71}$ The judges of England were known to believe that the union of the crowns of Scotland and England in the person of the king upon the accession of James VI of Scotland to the throne of England had worked a degree of union in their subjects. The purpose of Calvin's Case was to secure a judicial holding to this effect.

${ }^{69}$ As Gough recognizes. While agreeing with Holdsworth on the conservatism (so to speak) of Coke's views, Gough says, "What Coke would not have understood, however, was Holdsworth's affection for the doctrine of sovereignty." J. Gouch, supra note 61 , at 39 .

708 Co. Rep. 107, 118a, 77 Eng. Rep. 638, 652 (K.B. 1607).

${ }^{71}$ James $I$ and his House of Commons were at loggerheads on this issue; the matter was threshed endlessly, in and out of Parliament. See, e.g., F. Bacon, Tracts Relating to Scotland, in 2 The Works of Francis Bacon 138 (B. Montagu ed. 1841); James I, Speech to Parliament on the Union, in The Political Works of James I, at 296 (C. Mcllwain ed. 1918). See also Juricek, supra note 35; Wheeler, supra note 45. Bacon argued the issue in the Exchequer Chamber as His Majesty's Solicitor General. See Bacon, In the Case of the Post Nati of Scotland, in 15 The Works of Francis Bacon 193 (J. Spedding, R. Ellis, \& D. Heath eds. 1869). 
Robert Calvin, a Scot born after the accession of James to the English throne (hence post natus), sued for the recovery of land in England which he claimed to have inherited. Scots were aliens before James became King of England, and under English law an alien could not maintain such a suit. On hearing before all the judges of England in Exchequer Chamber, it was held that the post nati were not aliens in England. The result followed from the proposition that allegiance is personal and tied to the person of the king rather than to the law. Those born under the same allegiance could not be aliens one to the other, and so the post nati of Scotland might have, in England, the rights of Englishmen, despite the fact that they lived under separate law in Scotland, and the English Parliament had no authority there.

Thus far, it will be seen, Calin's Case provided the American colonists with firm support, for it was just such personal allegiance, without subjection to the English Parliament, that they claimed as their position in the British Empire. Scotland, as McIlwain put it, was their constitutional ideal. But Calvin's Case, in a dictum laid down by Edward Coke, was if anything more useful to their opponents-or so those opponents said, and so history has echoed.

[I]f a King come to a Christian kingdom by conquest, seeing that he hath witae et necis potestatem, he may at his pleasure alter and change the laws of that kingdom: but until he doth make an alteration of those laws the ancient laws of that kingdom remain. . . . But if a King hath a kingdom by title of descent, there seeing by the laws of that kingdom he doth inherit the kingdom, he cannot change those laws of himself, without consent of Parliament. Also if a King hath a Christian kingdom by conquest, as King Henry the Second had Ireland, after King John had given unto them, being under his obedience and subjection, the laws of England for the government of that country, no succeeding King could alter the same without Parliament. And in that case; while the realm of England, and that of Ireland were governed by several laws, any that was born in Ireland was no alien to the realm of England. In which precedent of Ireland three things are to be observed. 1. That then there had been two descents, one from Henry the Second to King Richard the First, and from Richard to 
King John, before the alteration of the laws. 2. That albeit Ireland was a distinct dominion, yet the title thereof being by conquest, the same by judgment of law might by express words be bound by Act of the Parliament of England. 3. That albeit no reservation were in King John's Charter, yet by judgment of law a writ of error did lie in the King's Bench in England of an erroneous judgment in the King's Bench of Ireland. ${ }^{72}$

We can see the advantage which might be taken of Calvin's Case by the British and their later scholarly supporters: Scotland might have been the colonists' constitutional ideal, but Ireland was assumed even by Mcllwain to be the closest constitutional parallel to the colonies, and the English Parliament might bind it. There was no question that one could, by the doctrine of Caluin's Case, live under allegiance to the King of England without subjection to the English Parliament; but that held for a kingdom by descent-a kingdom by whose laws the king came into his title (Scotland or Hanover)-rather than a dominion by conquest (Ireland). Moreover, applying common law principles, Coke recognized only descent and conquest as possible modes of acquisition. "The King's possessions are discussed in terms of English property law, itself the product of feudalism, a fact which explains the archaic doctrine of the judges that what does not come by descent is by conquest." ${ }^{33}$ By English property law, that is, all land is in tenure: all titles are derivative, there is no recognition of res nullius, and there is thus no room for the mode of acquisition which later came to be called colonization, plantation, or settlement. ${ }^{74}$ In such a system, actual, factual conquest is irrelevant; thus attempted distinction of Ireland on the ground of conquest was futile, as indeed were protestations by the Irish that they had not in fact been conquered.

727 Co. Rep. la, 17b-18b, 77 Eng. Rep. 377, 398 (K.B. 1608) (emphasis supplied). Coke's was only one of a number of opinions in the case, but it is his view that we are interested in, in part because we wish to see what support there was for the colonists in the law or principles of one who was in no sense a "high prerogative" man. $C f$. text accompanying notes 171-72 infra.

${ }^{73} \mathrm{~J}$. Smith, supra note 35 , at 468. See also J. Goebel, The Struggle for the FalkLand Islands 85-87, 102-05 (1927). For later developments, see id. 105-07.

${ }^{74} \mathrm{John}$ Adams used this state of the law in Coke's time to claim that, since colonization was casus omissus at common law, the American case was a novel one for which there were no precedents. See 4 The Works of John Adams 121, 149, 159, 170 (1851); text accompanying note 138 infra. 
Thus, while the theory of personal allegiance bolstered the American case, the statement that Ireland might be bound by the English Parliament virtually destroyed it. And, to make things worse, it has always seemed that in Calvin's Case Coke went out of his way-to the extent, indeed, of deliberately distorting an earlier judicial holding-to underline the power of the English Parliament over Ireland. The distortion has been thought to have occurred in this passage:

That Ireland is a dominion separate and divided from England, it is evident from our books, $20 \mathrm{H}$. 6. 8. Sir John Pilkington's case. ... And 2 R. 3. 12a. Hibernia habet Parliamentum, et faciunt leges, et nostra statuta non ligant eos, quia non mittunt milites ad Parliamentum (which is to be understood, unless they be especially named) sed personae eorum sunt subjecti Regis, sicut inhabitantes in Calesiâ, Gasonciâ, et Guyan. ${ }^{75}$

The parenthetical remark is an interpolation in a report of a case called the Merchants of Waterford Case. ${ }^{76}$ It is a reference to the so-called "naming doctrine," by which statutes were taken to bind the dominions only if they named the dominions. Coke's insertion of the italicized words clearly stands the sentence in which they were inserted on its head. The naming doctrine is, of course, an assurance against inadvertance, an admission that circumstances so differed in the dominions that it could not be assumed that all legislation for the realm would be suitable for the dominions, and a requirement that if Parliament should wish to bind the dominions it say so. Its relation to parliamentary power is by way of recognition that power exists. But the sentence taken from Waterford denies that power exists, and bases the denial on lack of representation. And, as James Wilson and others have remarked, if representation is the crux, what possible relevance can naming have? ${ }^{77}$ Even Schuyler called Coke's interpolation an "unwarranted gloss," ${ }^{8}$ and there is no doubt that it took a sentence denying parliamentary power and turned

757 Co. Rep. la, 22b, 77 Eng. Rep. 377, 404 (K.B. 1608) (emphasis supplied).

${ }^{76}$ Case of the Merchants of the City of Waterford, Y.B. 2 Rich. 3, f. 11 (1484), 2 Select Cases in the Exchequer Chamber Before All the Justices of England 94 (M. Hemmant ed. 1948).

${ }^{77} \mathrm{~J}$. Wilson, Considerations on the Nature and Extent of the Legislative Authority of the British Parliament (1774), in 2 The Works of James Wilson 501, 531 (J. Andrews ed. 1896).

${ }^{78}$ R. SCHUYLER, supra note 17 , at 65 . 
it into one asserting that power. Such extreme action suggests extreme anxiety on Coke's part to ensure that the power of the English Parliament, over Ireland at least, be well and truly established in law. Indeed, we might go so far as to gather from this that the law, before Calinin's Case, was otherwise.

There is another circumstance which leads us, once again, to conclude that Coke's purpose in Calinin's Case (in this aspect) was to maximize the power of the English Parliament. Coke, as we have seen, allowed the conqueror full and unchecked legislative power only until he instituted English law in the conquered territory; at that time "full control"79 shifted to Parliament, and the king could no longer alter the law without Parliament. Now while the conqueror's power was well known, in and out of England, Coke's limitation was out of whole cloth, unsupported and unsupportable. ${ }^{80}$ Here we have a clear example of judicial legislation. And to what end? Obviously to the end that no people living under English law live under the extraordinary power of a conqueror, and, at least by more or less common assumption, to the end that the English Parliament have control where English law prevails. The first purpose, of course, fits well with what we know of Coke's attitude toward royal power in England itself and the firmness, indeed passion, with which he insisted on the subordination of the prerogative to the common law. The second seems to indicate that Coke was earlier the Parliament-man than his opinion in Bonham's Case suggests.

I believe that if we reconsider Coke's opinion in Calinn's Case we will find that he was far from displaying an anxiety that the power of the English Parliament over the dominions be secured. While his concern for a check to the conqueror's power is unmistakable, there is no sign whatever of concern for the power of the English Parliament. There is, instead, a distinct recognition that the power of the English Parliament over Ireland (and, presumably, over any dominion ruled by English law) is anomalous, a reluctance to admit that power, and an attempt to minimize it. For, current opinion notwithstanding, there is no reason to think that when Coke declares that the king must, after the institution of English law, work through parliament, it is the

${ }^{79} \mathrm{~J}$. GoEBeL, supra note 25 , at 276.

80 "Coke's doctrine is so obviously a result of the developed political character of Parliament that we must be careful not to be misled by claiming for it any great historical validity." Id. 
English Parliament that he has in mind! To the contrary, it seems to me to be Coke's assumption that the parliament would be one granted the conquered territory. Any number of signs, textual and otherwise, point to this as the proper meaning.

First, the sentence we are considering: "Also if a King hath a Christian kingdom by conquest, as King Henry the Second had Ireland, after King John had given unto them, being under his obedience and subjection, the laws of England for the government of that country, no succeeding King could alter the same without parliament." 81 Now the preceding sentence uses the word parliament, talking of a kingdom by descent: "[the king] cannot change those laws of himself, without parliament." Mansfield tells us that Coke must be talking of England (therefore of the English Parliament), for he speaks of a country with a parliament. ${ }^{82}$ If Mansfield is right, the appropriate inference would be that whenever Coke says "parliament" he means the English Parliament. A moment's reflection, however, will tell us that Coke must be using this word generically; he means the parliament of the kingdom-any kingdom-gained by descent. Only if England were the only country with a parliament-and it was not-would Mansfield's inference be warranted. The appropriate inference, if any, would seem to be that when Coke uses the word "parliament" without specification he means it generically.

Then we have "2. That albeit Ireland was a distinct dominion, yet the title thereof being by conquest, the same by judgment of law might by express words be bound by Act of the Parliament of England." Parliament of England, Coke says "the Parliament of England." Moreover, he takes especial care to note this power; it is one of "three things to be observed," which would hardly be necessary if he had just said that the king, having granted the laws of England to Ireland, must legislate through the Parliament of England. Further, it is "by judgment of law" that the Parliament of England might legislate for Ireland. This is a reference to a judicial precedent. The tone is of setting out a rule, derived from precedent, which is, at a minimum, unexpected given those previously enunciated, and is perhaps out of line with them.

\footnotetext{
817 Co. Rep. la, 17b, 77 Eng. Rep. 377, 398 (K.B. 1608).

${ }^{82}$ Campbell v. Hall, 1 Cowp. 204, 211, 98 Eng. Rep. 1045, 1049 (K.B. 1774).

${ }^{83} 7$ Co. Rep. la, 17b, 77 Eng. Rep. 377, 398 (K.B. 1608).
} 
Finally, there was the fact that the kings of England had indeed legislated for Irish affairs more often through their Irish parliaments.

Coke evidently believed that the grant of English laws to Ireland put the English king in Ireland in the position of the English king in England-that is, without legislative power on his own, but only through a parliament. I would suggest that Coke's position on this was that of a parliament-man, not a Parliament-man, and indeed that Coke, had he not been forced to recognize certain legal decisions, would not have allowed the power of the English Parliament over a conquered country to which had been given the laws of England. His allowance of the power is reluctant and, furthermore, decidedly based on, indeed the last shred of, the conqueror's absolute power: "the title thereof being by conquest, the same by judgment of law might by express words be bound by Act of the Parliament of England." ${ }^{84} \mathrm{He}$ takes the same tone of having to state an anomalous rule when he goes on to note that "albeit no reservation were in King John's Charter, yet by judgment of law [!] a writ of error did lie in the King's Bench in England of an erroneous judgment in the King's Bench of Ireland." 85 Obviously, far from assuming that the grant of English law is equivalent to the imposition of English rule through the English Parliament and courts, Coke saw it merely as a requirement that the conqueror act in Ireland as he did in England.

${ }^{84} I d$.

${ }^{85} \mathrm{Id}$. This jurisdiction of the English King's Bench over judgments of the Irish King's Bench was irksome to the Irish and an embarrassment to those who denied the authority of the English Parliament. One Irish advocate distinguished the jurisdiction of King's Bench thus:

[I]f writ of error be brought in England to reverse a judgment given in the

King's Bench of Ireland, the Judges of England are not to alter or change the laws of Ireland, or to give judgment according to the laws in England in such case, but according to the laws in Ireland.

R. SCHUYLer, supra note 17 , at 65 , quoting ANonymous, A DECLARATION SETTING FORTH HOW, aNd BY WHAT MEANS, THE LAWS aNd STATUTES OF ENGLAND, FROM TIME TO TIME, CAME to BE of Force iN Ireland (1644). Molyneux, too, distinguished King's Bench from Parliament. Parliament, he said, "claimed a jurisdiction of their own; and their court is not the king's court, in that proper and strict sense that the king's bench is." $W$. Molyneux, supra note 36 , at 85-86. Schuyler, characterizing this as "bad history and bad law," R. Schuyler, supra note 17 , at 83 , seems to me to be clearly right only on the second count, and that only because of that distance between law and reality which induces historians to say that lawyers may overlook gulfs but historians cannot. Moreover, Schuyler himself seems to point out the problematic nature of his position by saying, "Nor, when Molyneux wrote, was the king's assent a foregone conclusion 
It must be noted that Coke did not tie the authority of the English Parliament to the grant of English law. There is no implication here that one cannot live under English law without subjection to the English Parliament. ${ }^{86}$ Coke does not say that the English Parliament entered the picture with the grant of English law, and there is not the slightest reason to think that he did not assume the English Parliament's conciliar role from the moment of acquisition of a territory by conquest. Nor is there any ground to think that he saw the English Parliament in a different position vis-à-vis the dominion after the grant of English law; what he did see was that it was then surprising, that it was an anomaly for a country under English law to be subject to a parliament not its own.

That Coke would have avoided the conclusion that the English Parliament had authority over Ireland, had he been able, is an hypothesis that fits well with the forensic requirements of Calvin's Case. Coke's problem was this: with Scotland certainly a distinct dominion, he had to establish that Scots (or at least post nati) were "no aliens" in England. Ireland's usefulness as precedent or analogy increased with its separateness or distinctness, for the Irish were "no aliens"; therefore it was to Coke's advantage to put the stress upon Ireland as a distinct dominion. Subjection to the English Parliament and English King's Bench were, in this effort, something of an obstacle. Coke would not have been anxious to make much of them; but, faced with the "judgment of law" in each case, he could not deny them and chose, not to ignore them, but to explain them away as the result of conquest. But the effort is always to maximize the distinctness and the concurrent nonalienity, while playing down the subjection. After a number of illustrations of the distinctness of Ireland, Coke comes to the point:

Might not then the like plea be devised as well against any person born in Ireland, as (this is against Calvin

\footnotetext{
..." Id. 84. Why mention the disappearance of the royal veto at all? That is a slice of history which, according to Schuyler, had nothing to do with law. See id. 83-84.

${ }^{86}$ This was the endless refrain of the supporters of Parliamentary authority. Molyneux, on the other hand, saw the grant of English law as a waiver of the conqueror's rights, as a grant (a "boon," see generally text accompanying note 168 infra) rather than an imposition. It seemed obvious to him that to grant English law was to grant the right "of being governed only by such laws to which they give their own consent by their Representatives in Parliament." W. Molyneux, supra note 36, at 32. My sense is that Coke was in tune with Molyneux in his conception of what the law should be.
} 
that is a postnatus) in Scotland? For the Irishman is born extra ligeantiam Regis regni sui $A n g l ', \mathcal{E}^{2} c$. which be terba operativa in the plea: but all men know that they are natural-born subjects, and capable of and inheritable to lands in England. ${ }^{87}$

Thus did Coke develop the forensic utility of Ireland without denying the power of the English Parliament over Ireland. Once we have seen this, we can clear up a puzzle or two. In the quotation from the Merchants of Waterford Case, ${ }^{88}$ why did Coke interpolate a clause which (1) actually contradicted the sentence he was quoting and (2) seems to have introduced the doctrine of English Parliamentary power over Ireland in the face of a contrary precedent? To understand this we must know that there were two phases to this case; we may call them Waterford $I$ and Waterford II ${ }^{89}$ The quotation which denied the power was from Waterford I; in Waterford II (the final phase) the power was affirmed. And, by the time Coke wrote, it was clearly the law. ${ }^{90}$ Thus the interpolation, though making nonsense of the quotation, actually converted it into an accurate statement of the law. Why, then, it will be asked, did Coke quote an erroneous statement of law from Waterford $I$ and turn it upside down instead of simply citing Waterford II for the proposition that the Parliament of England did have power over Ireland? Because that is not the point he wished to make at that juncture. He was, recall, trying to establish the separateness of Ireland. Waterford I had just the quotation he needed. And if it needed a bit of touching up for the sake of accuracy, well, that could be managed. And if the touching up led to centuries (literally) of puzzlement and irritation at the "unwarranted glossing," at the arbitrary, unreasonable, and unjustified insertion of the existence of a power where

877 Co. Rep. 1a, 23a, 77 Eng. Rep. 377, 405 (K.B. 1608).

${ }^{88}$ Text accompanying note 75 supra.

${ }^{89}$ Case of the Merchants of the City of Waterford, Y.B. 2 Rich. 3, f.11 (Ex. 1484), 2 Select Cases in the Exchequer Chamber Before All the Justices of England 94 (M. Hemmant ed. 1948) (Waterford I); id., Y.B. 1 Hen. 7, f.3 (Ex. 1485) (Waterford II). ${ }^{90}$ See Thorne, Introduction to A Discourse UPON THE Exposition AND UNDerstandings of Statutes 34 (S. Thorne ed. 1942). The controversy over Ireland is, as Bailyn truly says, "remarkably complicated." 1 B. BAILYN, supra note 31 , at 723. Donaldson has considered it most thoroughly (and superbly well). See Donaldson, supra note 35. Donaldson sees practice as dispositive ("communis error facit lex"), id. 373; his conclusion is that, in English law, the English view was right. Id. 374. "Perhaps the truest legal analysis of the situation was that the custom of legislating for Ireland evolved into a legally recognized right." $I d .357$. 
power was denied, at the distortion of a holding, at the invention of a doctrine that Parliament might bind if it named, well, that could hardly have been anticipated. ${ }^{91}$ The great point was that Coke made his point that Ireland was oh! so very separate and still managed to state the law as he knew it, and as in truth it was. $^{92}$ What matter the confusions of posterity?

\section{Parliamentary Debates and Institutes}

Given all this, it might be thought that the exigencies of advocacy - the need to maximize the analogic value of Ireland-explain altogether Coke's minimization of the role of the English Parliament in dominions living under English law. But his attitude was exhibited on other occasions, and in sum the evidence seems to me to indicate that his major concern was for what we should call government by consent. Coke's views on this matter of legislative authority in Ireland can be gleaned from other sources. ${ }^{93}$ For example, the issue arose in 1621 in the very form in which Thomas Jefferson would have had it arise in 1774:94 James I rebuked his House of Commons for meddling

${ }^{91}$ Of course there may never have been any puzzlement, although irritation there was; Wilson and Adams were both quick to point out the arbitrary nature of what Adams called "Lord Coke's parenthesis." Wilson emphasized the absurdity, if representation is the basis for the lack of power, of granting power to legislate by naming. 2 The Works of James Wilson, supra note 77, at 531. Adams said further that the parenthesis was arbitrary and groundless unless based on an arbitrary royal power stemming from conquest or on consent. 4 THE WORKS OF JOHN ADAMS, supra note 74, at 163 . Of course, these are the arguments which would be made by the skilled advocate for the colonies, even if he were as aware as we now are of the existence of Waterford II and of the validity of Coke's addition as a proposition of law.

${ }^{92}$ Schuyler saw that Coke cited the first opinion to show the separateness of Ireland and then interpolated "to reconcile this with the doctrine of the supremacy of the English Parliament over Ireland . . . R. SCHuYLER, supra note 17, at 65 . I would say, "to reconcile this with the decision that the king may use his English Parliment in a conquest."

${ }^{93}$ Wheeler made the point that "Coke is not so dogmatic on [parliamentary power over dominions] as we have been led to believe." Wheeler, supra note 45, at 593. And Wheeler introduces some of the evidence which follows here. Though Wheeler does not read Calinn's Case as I do, he does see that Parliament "enters negatively." His conclusion is that "it is not unlikely that [Coke] may have denied the authority of Parliament over Ireland." Id. 594. See also Juricek, supra note 35 , at 662 , noting that, in James' view, "If the extension of English law had curbed the king's authority, the subsequent creation of an Irish Parliament had certainly limited that of the English Parliament," and that James "seemingly" and Coke "definitely" required Irish Parliamentary approval of acts of the English Parliament. Juricek goes into this whole matter in some depth.

${ }^{94}$ See T. Jefrerson, supra note 43. 
in Irish affairs and demanded that such matters be left to him. ${ }^{95}$ Of this (and similar action taken by the unfortunate James and his more unfortunate son) Schuyler comments that Stuart high prerogative notions were at play-more than intimating that, by law, the king had no such claim. ${ }^{96}$ There was certainly opinion to that effect in Commons, but the opinion of Edward Coke was to the contrary:

What we may doe in a parliamentary fashion, then what is fitt to doe. Ireland was never totallie reduced untill the Kinge came, but that a north doare was ever open. If Ireland, which is the back doare to England, if that be safe and the Navy riggd, no invasion can perplex us. If we doe know any thing that we know doe hinder this end, it is for the honor of the Kinge we should enquire of it, for his Majestie hath bin ever ready to reforme it. The charge now is reduced to 2000li. per annum. It is fitt and lawfull to complayne. Petitions that come out of Ireland hath bin alwayes receaved and a Comitte appointed of the lords to present them. They are to have a parliament and have bin ever since $17 \mathrm{H} .7$ [sic, $10 \mathrm{H}$. 7]. Therfore greevances may be preferred to the King by this parliament which his Majestie may be pleased to reforme by his Majesties order or may call a parliament. ${ }^{97}$

${ }^{95}$ For the conflict in the 1620 's between the early Stuarts and their Parliaments over parliamentary intervention in dominion affairs, see 2 Commons Debates 323-24, 386 (W. Notestein, F. Relf \& H. Simpson eds. 1935); 3 id. 81-82, 89-92, 119, 297-98, 416-17, 441-42; 4 id. 255-56; 5 id. 98-99, 101-02, 118-21, 127-28, 205, 227, 330, 355-56, $358,378-79,382 ; 6$ id. 100-02, 112-14, 135; 1 Proceedings and Debates of British Parliaments Respecting North America 35-40, 49-82 (L. Stock ed. 1966).

${ }^{96}$ R. SChUYLER, supra note 17 , at 22 et seq. Of the 1624 episode in which James I warned Parliament off consideration of Virginia affairs, Schuyler reports: "The royal order, we are told, 'was assented to by a general silence, but not without whispers that by such means any business might be taken out of the hands of Parliament.'" Id. 23. We are indeed told that; it was in a letter from Sir Francis Nethersole to Carleton. 1 Proceedings and Debates of the Bristish Parliament respecting North America, supra note 95 , at $68 \mathrm{n} .40$. We are also told, and in the same footnote, that Sir Isaac Wake wrote to Conway, "The king's letter which was received with universal applause has quieted the great schism caused by the Virginians," and that John Chamberlain wrote to Carleton that it was "the best course that could have been taken, and no doubt most pleasing to the major part." Id. Stock, like Schuyler and others, singles out the one comment as worthy of mention. Stock, Preface to id. xi-xii.

${ }^{97} 6$ Commons Debates, supra note 95, at 101. Note, in connection with Coke's use of the word "parliament" in Calvin's Case, that here "this parliament" means the English Parliament and "a parliament" means the Irish Parliament. Of course, this may be the diarist rather than Coke. 
It was, evidently, a real question to Coke whether Ireland was even to be held a subject suitable for consideration by the House. Having resolved that it was (given its critical position as England's "back doare" and the fact that it had not even been completely subdued until the reign of James I) a fit subject for Englishmen to deliberate upon, he concluded that the English Commons might present to the king their grievances on Ireland, even in the form of laws (as we are told by another diarist), ${ }^{98}$ but the laws were to await passage through the Parliament of Ireland rather than the Parliament of England. Or, if the matters were not those requiring parliamentary action, the king alone might act. As "Cicill" put it, "[T]his house doth not thinke by way of bill to deale for Ireland, but as a great Councell to the King to informe him of that he know not concerning Ireland, as a Member to make the Kings glory the greater."99

Coke's precise position was that by statute (Poyning's Law) ${ }^{100}$ legislation for Ireland was to go through the Irish Parliament. ${ }^{101}$ Since this was an Irish statute, the inference would be that a conqueror (or his successors) may choose to exclude the English Parliament for the future without the consent of the English Parliament, then or later, to its own exclusion. On the other hand, although most legislation for Ireland had been enacted through the Irish Parliament since Poyning's Law, some of it had gone through the English Parliament. ${ }^{102}$ It was open to Coke, had he wished to exploit this fact in the interest of the English Parliament, to claim that although by construction of Poyning's Law the king was meant to legislate for Ireland through the Irish Parliament as a rule, the English Parliament had the power to do so when it saw fit. As we have seen, he did nothing of the kind. The option to legislate through the English Parliament evidently remained-but to the king. Again we see a lack of concern for the power of the English Parliament.

Turning to Coke's Institutes we find confirmation of our sense of Coke as the parliament- rather than Parliament-man.

${ }^{98}$ See 3 id. 91.

996 id. 114.

10010 H. 7, c. 22 (1495).

${ }^{101}$ No bill could be introduced in the Parliament of Ireland unless approved by the King and his Council in England.

${ }_{102}$ See Donaldson, supra note 35 , ch. 7. Donaldson believes that this continuation of English law-making for Ireland was contrary to the intention of Poyning's Law. 
The pertinent section is titled Of the Kingdom of Ireland. ${ }^{103} \mathrm{Hav}-$ ing remarked that Ireland was to have its own parliament, Coke treats the power of the English Parliament over Ireland thus:

Sometimes the king of England called his nobles of Ireland to come to his parliament of England, \&c. And by speciall words the parliament of England may binde the subjects of Ireland, as taking one example for many.

10 Octobris rex affectans pacificum statum terrae Hiberniae, mandavit Ricardo de Burgo com' Ulton et allis nobilibus terrae praedictae, quod sunt ad parliamentum suum....

An excellent president to be followed, whensoever any act of parliament shall be made in England, concerning the state of Ireland, \&c. ${ }^{104}$

In short, when announcedly giving an example of the binding of the subjects of Ireland by the Parliament of England, Coke in fact presents a sample of a summons to the nobles of Ireland to come to Westminster, and urges that that path be followed. ${ }^{105}$ Coke did not fail to recognize that acts of the English Parliament might, even after Poyning's Law, bind Ireland, but his concern that the Irish be ruled by their own parliament was such that one must think it more probable than not that he would have liked to deny the authority of the English Parliament over Ireland. ${ }^{106}$

We must not select evidence to support our tendentious assumptions and ignore that which may tend to rebut them. First, it is true that in the Institutes Coke recognizes that acts of Parliament may reach not only Ireland, but the Channel Isles and the Isle of Man. ${ }^{107}$ As evidence on the question of law, these are unfortunate precedents for the colonists-more so, indeed, than Ireland. But we are interested in what we may discover of Coke's sense both of what the law was and what it should be. How, for example, does this fit in with the descent-conquest scheme? We should have thought these territories by descent; thus, like Scot-

${ }^{103}$ E. Coke, The Fourth Part of the Institutes of the Laws of England: CoNCERning THE JuRISDiction of Courts 349-61 (1809 ed.).

${ }^{104}$ Id. 350 .

${ }^{105}$ John Adams saw the significance of this passage. See 4 ThE Works of JoHN ADAMs, supra note 74, at 164-5.

${ }^{106}$ See also Parliament in Ireland, 12 Co. Rep. 110, 77 Eng. Rep. 1386 (K.B. 1613), where Coke seems to be stating the law so as virtually to deny that English acts since Poyning's Law bind Ireland.

${ }^{107}$ E. Coke, supra note 103, at 282-87. 
land, they should be beyond the reach of the Parliament of England. It may be that Coke was conscious of this difficulty; in any event, we find him writing, of Man, "Nota, the titl of the king by conquest is affirmed by parliament." 108 And, of the Channel Isles, "Both these isles did of ancient time belong to the duchy of Normandy: but when king $H .1$ had overthrown his elder brother Robert duke of Normandy, he did unite to the kingdome of England perpetually the duchy of Normandy together with these isles ...."109 While ambiguous, this might be intended as a suggestion that the Channel Isles (like Man) might be though of as conquests.

It is also interesting, though not perhaps terribly significant, that Coke states the power of Parliament in the Channel Isles thus: "They are not bound by our acts of parliament unlesse they be specially named"; ${ }^{110}$ grudgingly, you might say, or at least negatively. And then, of course, there remains the question, which is possibly the critical question, whether Coke would have supported the power of the king to keep his Parliament of England from legislating for these territories as for Ireland.

It may indeed be suggested that Coke's support of the royal. option to keep the English Parliament out of dominion affairs may not have extended to the American possessions. And that is a distinct possibility. The relevant evidence comes from the proceedings in Parliament over a matter of fishing rights off the coast of North America. ${ }^{111}$ James I had granted to Sir Fernando Gorges and the Council for New England a monopoly of such fishing and rights of confiscation in the event of infringement. Parliamentary sensitivity to royal monopoly in this period is well-known; on complaint, steps were taken in two directions. First, a bill for free fishing was brought in. Second, the patent was alleged to be a grievance and the grievance machinery set in motion.

Coke is not reported as having spoken either in support of, or against, the claim made by Calvert for the king: "That if

${ }^{108} I d .282$.

109 Id. 286.

${ }^{10} \mathrm{Id}$. 287. "It was resolved ... that ... [no] general act of parliament did extend to the Isle of Man for the cause aforesaid, but by speciall name an act of parliament may extend to it." Id. 283. Coke does elsewhere point out "the extent of the jurisdiction of the parliament of England [in the dominions]," but he is speaking of the receipt of petitions, and obviously not of legislation, for one of the places mentioned is Scotland. Id. 10.

${ }^{111}$ See sources cited at note 95 supra. 
Regall Prerogative have power in any thinge it is in this: Newe Conquests are to be ordered by the Will of the Conquerour, Virginia is not anex't to the Crowne of England And therefore not subject to the Lawes of this Howse." 112 Coke did say, in the course of consideration of the bill, "Sir F. Gorges his patent condemned [i.e., as a grievance], for the clause, that none should visit with fishing upon the sea-coast. This to make a monopoly upon the sea, which wont to be free. A monopoly attempted of the wind, and the sun, by the sole packing and drying of fish." 113 This suggests to me that Coke did not, in this case, support the

1124 Commons Debates, supra note 95, at 256. This would seem to be an admission that a territory "annexed to the crown" was subject to Parliament in a different sense from a conquest not annexed to the crown. This is an important, complex, and utterly confused issue. My own understanding is that annexation to the crown initially had no such effect; it was another way of saying that a territory might not be alienated from the crown. Originally, that is, there seem to have been three categories: (1) conquests altogether at the disposal of the king, (2) those annexed to the crown, and therefore not to be alienated, and (3) those annexed to (or "made parcel of") the realm.

The position of Parliament does not seem to have been any different in the first two cases; the king might use his English Parliament or not. If a possession became part of the realm, then there was no distinction whatever between that territory and England. It was never true that a dominion had to be annexed to the realm before the king might legislate for it through his English Parliament-though certain of the colonists were to argue this and actually to succeed in provoking their opponents (but not Mansfield, who knew that it was neither accurate nor necessary) to claim that the colonies were part of the realm. On the other hand, it was not true that annexation to the crown somehow limited the option of the king to keep his English Parliament out of dominion affairs. However, there was a gradual change in sentiment as to the meaning of annexation to the crown.

By the early seventeenth century one finds opinions that such annexation gives Parliament power to "deale by way of bill" with a dominion against the wishes of the king. (Of course, by that time the same claim is made for conquests not annexed to the crown.) The most forceful expression of this (as I think) still-novel doctrine is that of Chief Justice Vaughan, who classified dominions as those "of the king" (Scotland) and those "of the crown" (Ireland $e t$ al). The latter, he said were subject to the English Parliament; and, further, the Parliament of Ireland "cannot make itself not subject to the laws of, and subordinate to, the Parliament of England." Craw v. Ramsey, Vaughan 274, 292, 124 Eng. Rep. 1072, 1080 (C.P. 1670). That is just what Coke said Poyning's Law had done. We have no reason to think Vaughan's was an accurate account of the law. Indeed, his contemporary, Attorney General Sir Heneage Finch, thought otherwise:

For though an English Act do in truth bind Ireland, whatever they say there: yet most certainly it binds Ireland no longer, than till it be repealed in Ireland; so that all settlements in England will be unsettled by the next Parliament in Ireland. . . . For it is absurd and impossible to suppose a Parliament indued with a legislative power as Ireland hath, and yet the same Parliament, should be disabled to act legislatively.

2 T. Carte, An History of the Life of James, Duke of Ormond, app. XCI, at 82, quoted in Donaldson, supra note 35, at 364 .

1131 Proceedings and Debates of British Parliaments respecting North AMERICA, supra note 95, at 69 . 
king. But he seems to be giving his approval to the bill on the ground that it concerns the sea, wind, and sun, rather than a territory held by conquest. The distinction is not altogether persuasive, perhaps, for fishing rights included claims to the incidental use of land and timber. Nevertheless, Coke put it in those terms, and, however we may be struck by the distinction, it would seem that he was fortified in his own eyes by the belief that the question of a conquered territory and its governance was not really involved. And indeed, penumbrae we have always with us, and a line which is drawn too far over for all to accept it is a line nonetheless. ${ }^{14}$ Coke's stand, therefore, tells us little of his feelings about "conquests."

We know also that Coke chaired the grievance committee, and reported on the findings that the patent was a grievance both in the grant and in the execution. ${ }^{115}$ It is evident that Coke approved the grievance procedure; this matter, like Ireland, was a fit subject for Englishmen to deliberate upon. Finally, we are told that Coke said that since New England was held "of his Majestys house of Greenwich, so then the law thereof must be the law of old England, for of what place soever a thing is held it is subject to the same custom as the place of whom it is holden."116 There were those who argued that the tenurial posi-

${ }^{114}$ A full exploration of the imperial constitutional issue (which I hope to complete someday) must take into account this problem of line-drawing. The historical materials are replete with suggestive and tantalizing items on this. For example, Bacon distinguished statutes "for the good ordering of the governments" in a dominion from those "for the liberties and good usage of the subjects of those parts when they come hither, or 'vice versa' for the restraining of the abuses and misdemeanors of our subjects when they went thither." 2 ThE WORKS of Francis BACON, supra note 71, at 182 . In Campbell v. Hall, 1 Cowp. 204, 210, 98 Eng. Rep. 1045, 1048 (K.B. 1774), Mansfield said: "There are some Acts of Parliament relative to each of these conquests that I have named, but none for any change of their laws . ..." Goebel suggests that if a pattern can be discovered in the division of function between small and large council, or Council and Parliament, in the fourteenth century, it is "that the act of Parliament will be used where the profit of the realm is involved, especially in matters of general commercial interest; e.g., the staple and the traffic in wine. Otherwise we have inconsistency . . . " Goebel, supra note 35, at liii. Since much of the earliest history of this topic involves the adjudicative rather than the legislative function of "Parliament" (even if at the time fused into a single law-speaking function), jurisdictional immunities now associated with adjudication played a part, and led to distinctions of this kind. See id., passim, but especially xxii-xxiii. Thus the immunity of Ireland posited in Waterford I was said to extend to "terris et rebus illis efficiendo." See Thorne, supra note 90.

1151 Proceedings and Debates of Brirish Parliaments respecting North AMERICA, supra note 95, at 50 .

${ }^{116}$ Juricek, supra note 35 , at 706 . Juricek suggests that Coke might have been misinterpreted. I would think this very likely if he is supposed to have deduced the independent and indefeasible power of the English Parliament from the tenure provision, 
tion of New England-"holden of the manor of East Greenwich"-subjected that territory to the independent power of the English Parliament. ${ }^{17}$ Coke, it will be noted, only went so far as to assimilate the provision to the grant of English law, which, as we know from the case of Ireland, ended the conqueror's absolute power and forced him to legislate through $a$ parliament.

In short, all this casts not a shadow of doubt on the conclusions drawn from the case of Ireland: (1) that Coke wanted to do away with absolute royal rule, (2) that he wanted to give to all who lived under English law the benefits of representative government, and (3) that there is no sign that Coke saw the English Parliament as appropriately representing any but the King's subjects in England, except faute de mieux, in the absence of a representative body in the dominion-and then only until such a body appeared. Calvin's Case, insofar as it bears on this, tends to deny the representative character of the relation between the English Parliament and the Irish: "the title thereof being by conquest, the same ... might ... be bound by the parliament of England." It is only by the standard and, as I think, inaccurate reading of Calvin's Case that we convert all signs of Coke's wish to stamp principled limitation upon imperial rule into an avidity for the establishment of the supremacy of the English Parliament throughout the Empire. ${ }^{118}$

\section{Evaluation}

It is interesting that Schuyler should dismiss the attitude of James I and Charles I as illustrative of Stuart high prerogative notions, implying that it had no basis in law. This would seem to indicate a belief that by the seventeenth century the conciliar basis of parliamentary competence in the dominions was gone

but not unlikely that he would have been eager to see it as bringing English law into play; Gorges' grant was illegal under English law. See 1 Proceedings and Debates of Parliaments respecting North America, supra note 95, at 57-61. As Coke made clear when a similarly illegal patent to the Greenland Company was under consideration, the declaration of nullity must be made by the common law courts: "Diverse clauses in the patent are ag[ains]t the lawe, but lett us goe the old way, wee cannt but give our opinions that this patent is a grieveance." $I d .86$.

${ }^{117}$ Id. 33 n. 30.

${ }^{118}$ Of course, the most impressive sign of Coke's belief in the supremacy of Parliament is the famous passage in the Institutes: "Of the power and jurisdiction of the parliament, for making of laws in proceeding by bill, it is so transcendent and absolute, as it cannot be confined either for causes or persons within any bounds." E. Coke, supra note 103 , at 36 . See text accompanying notes 171-72 infra. 
and a new independent power resided in Parliament. For the essence of the conciliar theory in this context is its "might but need not" quality. ${ }^{119}$ The king might call in his English Lords and Commons, but he might equally well act on his own. So long as that remained true the theory of English parliamentary authority over the dominions was not, strictly speaking, a theory of English parliamentary power at all; the only power in sight was the king's. The conciliar theory is itself as high prerogative as they come-and Schuyler's comments about Stuart high prerogative sit ill with his enunciation of the conciliar theory. Or they signal, as said, his conviction that the basis of parliamentary authority over the dominions had changed by the seventeenth century. If this is so, then Schuyler is not merely saying, as Goebel suggests, "that the changes in [Parliament's] legal status wrought by political developments had resulted in no curtailment of its power in respect of the dominions"; 120 "no curtailment" (aside from begging the question) is misleading. If the king, by 1621, had no choice but to allow his English Parliament "by way of bill to deale for"121 his dominions, then the changes in legal status wrought by political developments had resulted in an enlargement of the power of Parliament over the dominions. If it was not a significant enlargement, that must be because the king's power to withhold the royal assent enabled him to do at the end of the legislative process that which James would do at the beginning and by that means to keep control of dominion affairs out of the English Houses of Parliament. That was, indeed, one ground urged for the proceeding by way of bill: "for what is here done is done but by the King himself; for his Majesty hath a negative Voice, so as he may refuse whether any such Bill may pass or no, though it hath before passed both Houses." ${ }^{22}$ But can anyone doubt that the enlargement would become signifi-

${ }^{119}$ As Goebel seems to recognize: "Vaughan, 400, says Parliament might legislate but it was not necessary that it should!" Goebel, supra note 25 , at 276 . The exclamation point is entirely appropriate. As Goebel points out, the consensual element of feudalism (which would have obligated the king as lord to take the advice of his local council) was weakened by one or another means in the dominions. The result was more power in the king, to act on his own or through his English Council. See J. GoEbeL, supra note 35, at l-lix.

${ }^{120}$ Id. 273.

1216 Commons Debates, supra note 95, at 114; see text accompanying note 99 supra.

122 I Proceedings aNd Debates of the House of Commons, in 1620 ANd 1621 , Collected By a MeMber of that House 319 (1766), quoted in R. SChuYler, supra note 17, at 23. See 3 Commons Debates, supra note 95, at 82; 1 Proceedings and Debates of the British Parliaments respecting North America, supra note 95, at 36-37. 
cant when the royal negative went "to join what Maitland called 'that ghostly company of legal fictions,' "123 when it was relegated to the never-never land of law in a polity ruled by convention?

Schuyler has said that the speaker who urged the House to proceed on the ground stated held the sound legal view. ${ }^{124}$ That may or may not be. Keith, however, in calling it a "complete" answer to James would seem to speak with the voice of anachronism. ${ }^{125}$ The royal assent might be withheld from any bill; historically (legally?), one thing which separated prerogative matters from all others was that they might be kept from reaching the stage at which withholding the royal assent was all that was left to the king. If it is true that the king might protect his prerogative by the refusal of the royal assent, does that make it automatically the case that it was impossible to trench on the prerogative by proceeding by way of bill ${ }^{126}$ Such a view is, at the least, the destruction of a vital historical (legal?) difference between prerogative and everything else, and a giant step in the direction of disabling the king from protecting his prerogative.

Sophisticated observers have noted that the Americans, who called themselves whigs, in relying on their link with the king essentially took a tory, or high prerogative, stance and supported their position with evidence drawn from high prerogative sources. Even more sophisticated observers have seen that the desire for sole external authority in the king (and Privy Council) resulted from the perception that under those conditions there would shortly be no external authority with any force whatever. The shadowboxing was no less clear at the time than it has been since: royal government (long the fact) meant, more and more, government by the elected representatives of the people; and one need not now labor the rise of the colonial assemblies, their control of the purse strings, and the growing impotence of royal officials in the face of their opposition. That, after all, is why Parliament stepped in. But that means that the tory cast of the American position was an illusion and that the whig label long ago attached to the American position by not-so-sophisticated observers is deserved-unless we take whig to mean not representative government but government by the Parliament of

${ }^{123}$ See Heaton, supra note 28 , at 833 . Heaton uses this phrase to describe the demise of Parliamentary power over the entire Empire.

${ }^{124}$ R. SCHUYLER, supra note 17 , at 23.

${ }^{125}$ A.B. Keith, Constitutional History of the First British Empire 5 (1930).

${ }^{126}$ So it was reportedly put in the 1620 's. See Juricek, supra note 35, at 693. 
Great Britain. But one thing is clear in this game of "when is a whig not a Whig," and that is that parliamentary. authority on the conciliar theory is high prerogative and tory if ever anything was. Perhaps that is why we hear nothing of it in England from the Interregnum to the twentieth century!

It was-need we be told?-John Adams who saw most deeply into this whole problem. And, in the end, one can find between the lines (in Novanglus, where he did his most extensive wrestling with the legal issues) ${ }^{127}$ an awareness that it defeated him. But he gave it a noble run. ${ }^{128}$

\section{B. John Adams}

Adams saw the impossibility of denying that Parliament had legislated for the king's dominions; no perpetuator he of the myth that such exercise awaited the Interregnum, although every fibre of his revolutionary being must have longed to be able to assert that. But he also saw that this was a derivative authority only; he was not the only one to have seen this, ${ }^{129}$ but he was the only one (so far as I am aware) to have seen its importance. Adams was very careful to point out that parliamentary power was not the issue-that it was the power of the king which had thus been exercised. He signalled his perception of this historically unassailable point, and of its significance, by referring (with only occasional lapse) not to "the English Parliament," but to "the King's English Lords and Commons." Nothing, he insisted, had ever been at issue but the power of the king to use his English Lords and Commons; he quoted Barrington on Ireland: "This note most fully proves that it was supposed that the king, by this sole authority, could then introduce any English law; and will that authority be lessened by the concurrence of the two houses of parliament?" "130 If it was necessary to underline the derivative nature of the parliamentary

127 "Novanglus" was the pseudonym used by Adams in a series of published letters that were part of a celebrated debate-by-letter with Daniel Leonard, who wrote as Massachusettensis. For the latest edition of these debates see The AmErican Colonial Crisis: The Daniel Leonard-John Adams Letters to the Press 1774-1775 (B. Mason ed. 1972).

${ }^{128}$ See 4 The Works of John Adams, supra note 74, at 121-77. Adams' analysis of the legal issues deserves greater attention than it has received, or will receive herein.

129 "Upon what principle does the British parliament found their power? Is it founded on the prerogative of the king? His prerogative does not extend to make laws to bind any of his subjects ..." 2 THE Works of James WiLson, supra note 77, at 521.

130 4 THE WORKS OF JOHN AdAMS, supra note 74, at 154. 
authority - to deny that it was, at all, Parliament's-it was similarly vital to insist that the kingly power, which Adams admitted, to use his English Lords and Commons was only a permissible mode of exercise of an arbitrary power, and could not exist-and never had existed-except where there was such an arbitrary power in the king. The king might use his English Lords and Commons because he might equally and at whim not use his English Lords and Commons-or any other such body. "[A]llegiance was due from the Welsh to the king, jure feudali, before the conquest of Llewellyn, and after that to the crown, until it was annexed to the realm, without being subject to acts of parliament any more than to acts of the king without parliament." ${ }^{131}$ Finally, said Adams, "there is no fundamental or other law that makes a King of England absolute anywhere, except in conquered countries . . .."132

Adams was surely on the right track. By stressing the derivative nature of the so-called power and its position as no more than a manifestation of the arbitrary power of the king, he could say that one who would claim "parliamentary power" must be claiming arbitrary power in the king, for it had never otherwise existed. Here, of course, and maddeningly no doubt for Adams, he ran headlong into Calvin's Case, much as Coke in Calvin's Case had run headlong into Waterford $I I$. For the king had retained his option to legislate for Ireland through his English Lords and Commons after his arbitrary power had (according to Coke) ceased by the grant of English law. And here we can see Adams twisting and turning with indifferent success. The most promising escape would seem to be the claim that the colonies were not conquests; the claim was made, but its problematic quality was evident to Adams, as it is to us watching him writhe. New York was a conquest in fact; furthermore, Adams' beloved "country," Massachusetts, was originally a conquest in law. ${ }^{133}$ Adams indeed described the union of feudal and canon law principles that held sway at the time of settlement and under which "the king was absolute in America,"134 and however "impertinent and fantastical"135 these doctrines, he was plainly conscious of the difficulty of denying their force. Painfully aware that Ireland re-

${ }^{131}$ Id. 141 (emphasis supplied); see id. 135.

${ }^{132}$ Id. 127.

${ }^{133}$ Holt, indeed, classified Virginia as a conquest after colonization was recognized by English law. Smith v. Brown and Cooper, 2 Salk. 666, 91 Eng. Rep. 566 (1706).

1344 THE WORKS OF JOHN ADAMS, supra note 74, at 126.

${ }^{135}$ Id. 125. 
mained a formidably unfavorable precedent, Adams in effect surrendered and concluded that the authority of the British Parliament over Ireland was, in truth, arbitrary and unjustifiable. ${ }^{136}$

Adams found the Channel Islands a problematic precedent as well; his solution was straightforward enough. On the authority of Parliament therein he commented: "It is either upon the principle that the king is absolute there, and has a right to make laws for them by his mere will, and, therefore, may express his will by an act of parliament, or an edict, at his pleasure; or it is an usurpation." 137 Finally, he concluded,

[T] here is no provision in the common law, in English precedents, in the English government or constitution, made for the case of the colonies. ... It stands upon no grounds, then, of law or policy, but what are found in the law of nature, and their express contracts in their charters, and their implied contracts in the commissions to governors and terms of settlement."138

Adams, it appears, found only a store of blank cartridges in the magazine of common law precedent.

Was there live ammunition there? Was there something more Adams could have done with the line of argument he embarked upon? Was there something more he could have done with Edward Coke's law? Calvin's Case surely did stand in his way; for all my conversion of that case into an example of Coke's attachment to principled limitation, the fact remains that Coke did admit the power of the king, even after the grant of English law, to legislate through his English Parliament for the dominions. If he saw it only because he had to, given the judgment of law with which he was faced, he saw it nonetheless, and so did John Adams, and so must we. Indeed, it must be said that a rule of law which Edward Coke could not argue his way around when he had a mind to is a rule of law we might just as well not waste our time querying. We may note the precise import of the rule-that it is the power of the king rather than of Parliament and that the king might choose to exclude his English Parliament-but where does that get us? More precisely, where did

${ }^{136} \mathrm{He}$ did try to find a compact, an agreement by the Irish to be subject to the English Parliament; but not, I think, with much success or, indeed, much conviction. See id. 151-9.

${ }^{137}$ Id. 169.

${ }^{138} I d .170$. 
it get the colonists? George III, as they finally admitted, did not choose to exclude his English Parliament. George III, as he said, fought the battle of the legislature-by which is meant Parliament. Did he not, even under the conciliar theory, even by the law as set down by Edward Coke, even without regard to the parliamentary supremacy won in the Glorious Revolution, have a right to do that? It would seem that Coke's law, as opposed to Coke's principles, would result in power to George III to use his English Lords and Commons to legislate for the dominions unless it could be argued that something had occurred since Calvin's Case which had, after all, resulted in a "curtailment of the power of Parliament over the dominions." 139

That "something" must be, and the advocate for the colonists must argue, that the extension of the benefits of government by consent to the dominions after Caltin's Case was such that there was created an unbearable tension within the imperial constitution which turned Coke's anomaly into an impossible internal contradiction. Is it only dim and wilful whiggish vision

${ }^{139}$ The mind of the advocate would swing immediately to the fact that the king, whose power is at issue, might be said to have had no power with the conversion of the royal assent into a formality. It is true that we are told on all sides that that was relevant only to the justice and not to the law of the case. But one might argue that point, or argue at least that Edward Coke might have argued that point, if one were dealing, let us say, with the situation under George II, or George VI. Even then it would be an uphill struggle. But the colonists faced George III. They had thus to deny the jurisdiction of a Parliament acting under the direction of a king of whom the colonists' best friends were to allege that he had recaptured the prerogative in the guise of influence. Cf. Wheeler, supra note 45 , at 597 .

The desperate clinging of the colonists to "the best of kings," and the myth that he was un- or mis-informed, had a sound legal-historical basis, whether the colonists knew it or not. The immediate reason for the refusal to face facts about George III and his intention to fight the battle of the legislature was of course the reluctance to face revolution, or rebellion, as, on any theory, an act against the king would be. Separation of king from Parliament was essential. But, although the Declaration of Independence, as often noted, proceeded on this theory that an act directed against Parliament was in no way in violation of the constitution, ironically, by finally admitting that the king had conspired with "foreign jurisdictions" (i.e., Parliament), the Declaration strengthened the argument that an act against Parliament was unconstitutional. There was little one could do about this central paradox, little hope to make the case that before the Interregnum Parliament could not, if the king wished, legislate for the dominions.

And then, the strength of the case against parliamentary authority depends on the distance which it is fair to say that that institution has travelled from the council which once it was, and in which the origin of its legitimate (i.e., derivative) power is to be sought. Obviously this deduction of the de jure from the de facto (a common process in the search for the British Constitution) depends on the facts; resumption of control de facto by George III is an unfavorable circumstance, legally, for the colonists. George III did fight the battle of the legislature; and he did it best, in imperial matters at least, by recapturing the kingship which his immediate predecessors had let slip. 
that will spy such extension by the eighteenth century, as Goebel truly says of the fourteenth? ${ }^{140}$ That may be so, and there may be no more than the tendentious assumptions of bicentennial befuddlement (which will pass with the ushering in of 1977 and sanity) to support the hypothesis-but let us see the strength of the case, such as it is.

\section{The Illusory Power of English Law}

\section{A. Limitation on Royal Power in the Dominions}

Consider, first, Coke's new-hatched doctrine of limitation on the conqueror's prerogative in Calvin's Case. Nestled as it was, a viper in the bosom of the conquest doctrine, it has not received the recognition that the conquest doctrine has received; when we hear that Coke foisted a medieval system on the colonists or that they were ruled for a century and a half by Calvin's Case-when we hear, in short, of the "implications" of Calvin's Case-we may find that the reference is to the conquest doctrine. ${ }^{141}$ But the truth is that the implications of Calvin's Case were multiple and inconsistent, and, like the Gingham Dog and Calico Cat, eventually they ate each other up. Calvin's Case was not only anachronistic in the sense that it brought medieval doctrine into the seventeenth century, it was an exercise in anachronism-for the future was there as well. From the time of Charles II, the past invaded the present and loosed in the dominions royal power far beyond anything which would have been tolerated in the realm or had thitherto been know in the happily neglected colonies. Nor was the conquest doctrine ever judicially disowned; on the contrary, it was set forth with renewed vigor by Mansfield in $1774 .^{142}$ Nevertheless, if one reads the pertinent cases and opinions of crown law officers over the years from Coke to Mansfield, one may well be struck not by the support which emerges for royal power over the king's dominions but by the progressive diminishment of the power, not by the tyranny of the past but by the foretaste of the future. Judicial and administrative pro-

${ }^{140}$ See Goebel, supra note 35, at lii; text accompanying note 158 infra.

${ }^{141}$ See generally, e.g., Goebel, supra note 35, at lx-lxi; Goebel, supra note 63, at 51-52. But cf. J. SMITH, supra note 35, at 468-69, where it is noted that Coke's limitation on the conquest doctrine also served to guide royal action in the colonies-acting as a warning not to grant English law. See notes 144-48 infra \& accompanying text.

${ }^{142}$ See text accompanying notes 159-60 infra. 
nouncements, that is, document the flourishing of Coke's innovative check to the power of the conqueror.

The single most effective method for assuring survival to Coke's novel doctrine was to do that which Coke had not been prepared to do. Abandoning the restrictions of English real property law, later jurists recognized colonization as well as descent and conquest. ${ }^{143}$ This, of course, effected an automatic sharp decrease in the number of territories subject at all, for any length of time, for any period, to the conqueror's absolute power. Then there were those territories which were, inescapably, factually, conquests, but in which Englishmen had settled. Here it was obviously desirable somehow to avoid applying to the conquerors rules meant for the conquered. Thus Mansfield suggested by way of dictum that Jamaica might be treated as a colony, "the old inhabitants having left the island."144 But that situation did not conveniently obtain in every conquest. A grant of English law would have served, but in the end it was necessary to accept as a surrender of the conqueror's right to arbitrary rule any number of things short of actual declaration that the laws of England be in force, for such a declaration was hard to find; kings of late (warned, it has been suggested, by Calvin's Case) ${ }^{145}$ were not so obliging as John (surely never before so characterized!) had been in Ireland. Later monarchs tended to provide only that the laws of the territory be "not repugnant" or "as near as may be" to the laws of England-a standard and perhaps a "warning of surveillance,"146 but in any event not a grant of "the boon of English law."147 But there were always grants of legislative assemblies, and in Campbell $v$. Hall ${ }^{148}$ it was held squarely that such a grant constituted an irrevocable surrender of the king's rights as conqueror.

The cumulative legal force of these doctrines is considera-

${ }^{143}$ See Ánonymous, 2 Peere Williams 75, 24 Eng. Rep. 646 (P.C. 1722); Blankard v. Galdy, 4 Mod. 222, 87 Eng. Rep. 359 (K. \& Q.B. 1693); Craw v. Ramsay, Vaughan 274, 279, 124 Eng. Rep. 1072, 1074 (C.P. 1670); Geary v. Barecroft, 1 Sid. 346, 82 Eng. Rep. 1148 (K.B. 1666).

${ }^{144}$ R. v. Vaughan, 4 Burr. 2494, 2500, 98 Eng. Rep. 308, 311 (K.B. 1769). In 1724 the attorney and solicitor generals said that the question of taxation of Jamaica by the king depended on whether it "is now to be considered merely a colony of English subjects, or as a conquered colony." 1 G. Chalmers, Opinions of Eminent Lawyers on VARIous Points of ENGLish JURISPRUdence 223 (1814).

${ }^{145} \mathrm{Cf}$. J. Smith, supra note 35, at 468-69.

${ }^{146} \mathrm{Cf}$. Goebel, supra note 63 , at 95.

${ }^{147}$ A.B. KEITH, supra note 125, at 10.

${ }^{148} 1$ Cowp. 204, 98 Eng. Rep. 1045 (K.B. 1774). 
ble. Colonies were not conquests; conquests which had been granted legislative assemblies were not conquests; perhaps those which no longer contained any of the conquered were not conquests. Now it is possible to see in this no more than obvious application of Coke's novel doctrine in Calvin's Case. ${ }^{149}$ Or, one may think of it as creative extension of that doctrine. It is also possible to argue that of the possible concerns behind this development-the pragmatic, the self-protective, and the generous-the last trails by many lengths. We might even admit the likelihood of this-at least by Mansfield's day, if not Coke's. The sting was drawn from the conqueror's power because: (1) settlers would not tolerate treatment as a conquered people; (2) royal power must not wax fat on contributions from grateful colonial beneficiaries of royal license, lessening dependence on Parliament, nor must Acts of Trade and the like depend for their enforcement on the strength of character of royal governors and customs officials, ${ }^{150}$ and (perhaps only then) (3) Englishmen in Britain did feel a genuine whiggish reluctance to see fellow subjects under the yoke of unfettered prerogative.

The effect, however, is something else; it is evident that such a legal development is in the direction of self-determination and, whatever the wellsprings, must bring in its wake first "the pressures that representation in fact ... bring[s] to bear" 151 and then, in support, ammunition for the use of the advocate. And the pressures of de facto representation will, inevitably, mold the law. A perfect example of this phenomenon is the adoption by British law officers of the doctrine of usage.

We must first comment briefly on that which can hardly be explicated in a hefty volume: the status of English law in the colonies. ${ }^{152}$ It may be said with some safety that the common law at the time of settlement (or surrender of the conqueror's power) was generally thought to be in force, that the status of pre-

${ }^{149}$ See generally text accompanying notes $159-60$ infra.

150 "[I]t has been a notorious grievance that when the King himself cannot dispense with an act of Parliament, there have been customhouse officers who have practised it for years together in favor of those toward whom they were graciously disposed." J. Otis, The Rights of The British Colonies Asserted and Proved 58-59 (1764), in 1 B. BAILYN, supra note 31 , at 419, 464-65. See note 162 infra for a discussion of the 1767 Dominican case decided by the Privy Council.

${ }^{151}$ Goebel, supra note 35 , at liii.

152 The best discussion of the status of English law in the colonies is in J. SMrrh, supra note 35 , ch. 8 . 
settlement acts of Parliament was altogether uncertain, and that acts of Parliament passed after settlement were not in force unless they named the colonies. Perhaps the most distressing of the many problems presented by this configuration was the inability of the colonists to claim the benefit of certain fundamental protections which had been secured by the English Parliament in post-settlement acts not naming the colonies-for example, in the Habeas Corpus Act. In truth there was, as it was said, nothing to keep the colonists from initiating such legislation in their own legislatures. And in truth there was, as the colonists retorted, nothing to keep a royal governor or proprietor from vetoing it, and nothing to ensure its safe passage through the shoals of disallowance. A "precarious" situation this seemed to some; the long struggles in Jamaica and Maryland to remedy have been well and fully documented. ${ }^{153}$ The colonists' solutions were various and ingenious; at their heart (explicitly or otherwise) was the magnificently simple claim that all parliamentary statutes; pre- or post-settlement, were in force in the colonies to the extent that the colonists approved them. ${ }^{154}$ As we can see, this claim of right to parliamentary statutes was merely a paradoxical herald to the eventual claim of immunity from parliamentary power, however inconsistent therewith in sound logic. It was no more than a claim to legislative self-determination, or a gambit on the road thereto, and, what is more, it met with a fair degree of success. A new doctrine evolved; as it was put by Yorke, in answer to queries about the law in force in Maryland in 1729, acts of Parliament not naming the dominions are not in force "unless they have been introduced and declared to be laws, by some acts of Assembly of the Province or have been received there by long and uninterrupted usage or practice which may

${ }^{153}$ See A. Whrtson, The Constitutronal Development of Jamaica chs. 1,7 (1929); Sioussat, The English Statutes in Maryland, 21 John Hopkins Univ. Studies Nos. 1 1-12 (1903). A. Whirson, supra, should be supplemented by J. SMITH, supra note 35, at 476-80.

154 In 1680 the Lords of Trade asked the crown law officers this question: "Are not the subjects in Jamaica, who claim to be governed by the laws of England, bound as well by such laws as are beneficial to the King (e.g., subsidies) as by such as tend only to the benefit of the subject?" A. WHITSON, supra note 153, at 102. Much later James Wilson noted that the colonists had been accused of wanting all the benefits of Empire without the burdens. Wilson's reply was that the colonists, not being represented in Parliament, did not have the benefits and need not therefore submit to the inconveniences. "The opposite inference burthens the colonists with the inconveniences separated from the benefit ...." 1 The Works of JAMEs Wilson, supra note 77, at 468-69. 
import a tacit consent of the Lord Proprietor and the people of the colony that they should have the force of law there."155

Goebel has made what I take to be the playful suggestion that American resistance to the Stamp Act was designed to prove that the Act was impossible of performance and thus within the doctrine of Bonham's Case, even in its enfeebled Blackstonian version. ${ }^{156}$ And of course the inconsistency of practice with law has long been noted; as Andrews said, the colonists' position bore more resemblance to the facts of the case than did the official British position. ${ }^{157}$ But it is arguable that the tension between fact and law was a reflection of the tension within the law. Tension was guaranteed by the simultaneous operation of all the implications of Calvin's Case. The fact-which was law - that the prerogative was at its height in the colonies reinforced the sense of these as the king's dominions-the sense of the essentially conciliar role of the king's English Lords and Commons. The reduction of the king's power by English law, as well as by the ingenuity and effort of the colonial assemblies, suggests irresistibly the reduction in law of all external power and leads one irresistibly to the argument that a derivative power cannot rise higher than its source. The doctrine of subjection to Parliament, never weakened by holding or dictum, nullified all the

255 1 Chalmers, supra note 144, at 208. To the same effect is the opinion of Yorke and Wearge concerning Jamaica in 1724. Id. 229.

Among other things, the usage doctrine constitutes a ringing answer to a point made by one of our more outspoken modern contemners of the American case. A.B. Keith has heaped scorn on John Adams' theory that the colonists had never admitted the force ex proprio vigore of parliamentary statutes but had, in the case of the Navigation Laws, given tacit consent to their enforcement.

The obvious difficulty here arose, which [Adams] ignored, that it was impossible for mere tacit acceptance to create law for Massachusetts or any other colony. If an obligation was imposed by an Imperial Act, it is clear that either it applied proprio ingore to the colony or [sic? and?] was law there, or it had no application and had to be made law.

A.B. Kerrt, supra note 125 , at 378 . And, he says, the courts could not do it; it had to be by the legislature! To be consistent, Keith, as Holdsworth notes, $11 \mathrm{~W}$. HoldswORTH, supra note 56, at $243 \mathrm{n} .4$ (also noting that "the efficacy of usage to introduce an Act is recognized by 25 George II c. 6 \& 10"), refuses to accept the usage doctrine as law in his account of the status of English law in the colonies. See A.B. KEITH, supra note 125, at 184. Evidently the spokesmen for British law in the eighteenth century disagreed.

I am not contending that the colonists had never admitted the force, ex proprio vigore, of parliamentary legislation. They surely did assume some parliamentary power over the colonies until the 1770s. The precise nature of the assumption and its legal effect, if any, are critical issues, but they cannot be investigated in this article.

${ }^{156} \mathrm{~J}$. GOEBEL, supra note 63 , at 94 .

${ }^{157} \mathrm{C}$. ANDrews, supra note 33 , at 42. 
gains made over the years in the direction of self-determination by means of the doctrines of settlement, irrevocable surrender, and usage-gains made in and by law.

Thus, at least, must the advocate for the colonists argue. For all McIlwain's rejection of fundamental law as covering the full claim to immunity, the truth is that the case-whatever there is of it and such as it is-must rest on the claim that the fundamental law of government by consent was ensured by the British Constitution. "It is easy to be misled by Whiggish raptures over the growth of government by representation and consent within the realm into supposing that the dominions were equally blessed. The truth is that they were not." ${ }^{158}$ For the early period, of which these words were written, they are accurate. But eighteenth-century dominions were much, if not equally, blessed by the extension of the benefits of government by consent. They were blessed enough, perhaps, for us to see a direction that the "imperial constitution" was taking; and if we can see it, so could they. Or, put another way, they could see enough extension of such benefits (and so can we) to portend the development of something which might be called an imperial constitution in more than the purely descriptive sense-in the sense, that is, of principled limitation.

\section{B. The Limits to Limitation}

Principled limitation, however, is in the eye of the beholder. To the Mansfields there was no such development. To Mansfield and others the law remained that which Coke had spoken: A king might indeed lose his conqueror's power over a dominion; nevertheless he might continue to legislate for that dominion through the Parliament of England. We get Coke's new law and Coke's old law-what we do not get is Coke's recognition of anomaly despite the fact that over the years from Coke to Mansfield the anomaly might be thought to have deepened by the development sketched above; and that is because over the years from Coke to Mansfield we have lost Coke's principles. If all is taken and intended to be in aid only of parliamentary supremacy-self-protective, in my earlier terminology-there is, in truth, no anomaly to be seen. To see the law as Mansfield saw it we have only to turn to his opinion in Campbell v. Hall. ${ }^{159}$ 
In this famous and critically timed case, Mansfield held that by grant of legislative assembly to Grenada, the king had irrevocably divested himself of the power to tax except through that assembly or through Parliament. Along the way, Mansfield asserts the vitality and validity of the conquest doctrine with an eloquence which, given his views in general, could only have come from his knowledge that he was about to hold (1) that the conqueror's power had, in this case, been surrendered; and (2) that, in a sense, the conqueror's power had never existed. Here is the crucial passage:

[I]f the King (and when I say the King, I always mean the King without the concurrence of Parliament,) has a power to alter the old and to introduce new laws in a conquered country, this legislation being subordinate, that is, subordinate to his own authority in Parliament, he cannot make any new change contrary to fundamental principles: he cannot exempt an inhabitant from that particular dominion; as for instance, from the laws of trade, or from the power of Parliament, or give him privileges exclusive of his other subjects . . . ${ }^{160}$

This dictum, it will be seen, is susceptible of broad interpretation; and it has indeed been read expansively by Holdsworth, who (for once sounding Cokean) imports into it limitations of a "higher law" character. ${ }^{161}$ And that of course is the reading most agreeable to the colonists; for until 1774, however much the number of territories which might be thought of as conquests was cut down (by settlement doctrine, by surrender which converted a conquest into a colony, or even by the emigration of the conquered population), it had always been true that a conqueror, where, when, and while a conqueror, was truly a conqueror. Having the vitae et necis potestatem, he might give what law he would. It was, recall, this one-time existence of absolute and arbitrary power in the king that drove Adams to forsake the common law; for it was, as the case of Ireland demonstrated, open to a king who was once absolute to use his Parliament of England even when he had surrendered the conqueror's role. If the king was now thought by English law never to have been

${ }^{160} I d$. at 209, 98 Eng. Rep. at 1048.

${ }^{161} 11$ W. HoldsworTH, supra note 56, at 246. Bailyn may interpret Mansfield's passage this way as well; he reports it thus: the king "could make no law 'contrary to fundamental principles." " 1 B. BAILYN, supra note 31 , at 710 . 
absolute, but always subject to "fundamental principles," perhaps it could be argued that Adams' troubles were over.

But if this demolition of the conquest doctrine was argumentatively all-important to the colonists, it was a matter of the sublimest unconcern to Mansfield. As his examples suggest, the "fundamental principle" involved in Campbell v. Hall was parliamentary supremacy. ${ }^{162}$ It was because the king was subordinate to himself in Parliament (and whatever Coke meant by that word, Mansfield meant the Parliament of England), not because he was subordinate to a higher law, that he was circumscribed by fundamental principles. There never was, to Mansfield, a reduction of arbitrary power over the dominions (in the light of which parliamentary power could only seem anomalous) but only a shift of such power from king to king-in-Parliament. Indeed, Mansfield does not even present it as a shift; for all one can tell from his opinion, it had always been the case that the supreme legislative power, over the dominions as in the realm, was in Parliament. There is no hint of its derivative nature, or any suggestion that it had once been derivative. The substitution of nation for king - the loss of the feudal spirit-was complete by 1774; and it is evident in Campbell v. Hall, for all Mansfield's protestations of undiminished kingly power as conqueror.

The British, having reduced the area of operation of the conquest doctrine, had, of course, a pale echo of the problem facing the "Parliament" of 1649; always, eliminating the king (whether one left him his head or not) meant either letting the colonies go or subjecting them to the control of "this nation," of "the people of England." ${ }^{63}$ Inevitably the latter was the course chosen; thus when conquest came to be thought of as "by the

162 Mansfield certainly had in mind Northington's comments in the 1767 Privy Council case concerning the application of the Acts of Trade to Dominica. Northington said, first, that the Acts, having "words of futurity" in them, were in force in a conquered territory immediately upon its being taken into possession, without special royal promulgation, and, second, that neither the king nor his officers might suspend the operation of the Acts, or exempt any person therefrom. See J. Smith, supra note 35, at 496-99. "The doctrine of Northington, dispensing as it did with any explicit promulgation by the crown, amounted to a real diminution of this [lawmaking] prerogative. ... It is picked up eight years later by Mansfield, C.J., in his opinion in Campbell v. Hall (1774), in a way that suggests that this great judge regarded it to be settled law ...." Id. 499. It should be noted, however, that Northington's doctrine rested on the theory of anticipatory promulgation; by its terms it brought into force in a conquest only English statutes having "words of futurity" in them and was thus, it would seem, a severely limited (if real) diminution of the prerogative.

${ }^{163} \mathrm{See}$ text accompanying note 21 supra. 
British arms" instead of by the king as conqueror, it appeared self-evident that the conquered territory must be "subject to the Legislature, the Parliament of Great Britain."164 When tenurial principles were discarded and settlement recognized, that settlement was assumed to be with the permission, not of the king, but of the legislature of Great Britain; and settlers (as Mansfield put it) "are more emphatically subjects of Great Britain than those within the realm ..."165 That much is clear. But it would seem equally clear that this substitution of nation for king worked two ways vis-à-vis the colonists. When conquest was no longer by the king but by British arms, it became apparent that those who stayed in the conquered territory were the conquerors and could not be treated like the conquered. When Englishmen might, in contemplation of law, settle colonies, then the notions of dependence associated with conquest were irrelevant and inappropriate.

It was half-vision, in the pre-Revolutionary decades, that registered only the first of these sets of implications. And this visual defect continues (with less excuse) in some modern commentators. Keith, for one, displays it in all manner of ways. He tells us, for example, that "it required little acumen to deduce" from the law of Calvin's Case that in a settled colony the subjects enjoyed English law as of right. ${ }^{166}$ But the doctrine of settlement cannot be deduced from Calvin's Case. It is a creative extension, by way of judicial legislation, of the principles behind Coke's own bit of law-making in Calvin's Case. Keith's minimization of this judicial creativity tends to blind him to its potential.

Moreover, Keith, commenting on American attempts to distinguish Ireland on the ground of conquest, says: "[T]here was no reason why the power of Parliament should be deemed to extend to conquered lands rather than to settled lands; indeed the presumption rather was the other way."167 Well, of course, the presumption was that, as to conquered lands, the king might keep his Parliament of England out. If that had been all that Keith meant, he would be right. But it was not. He meant that

${ }^{164}$ Campbell v. Hall, 1 Cowp. 204, 208, 98 Eng. Rep. 1045, 1047 (K.B. 1774). I do not suggest that this was never heard until the 1770 s, but only that it was accepted and well-nigh invariable by then.

${ }^{165} 16$ Parliamentary History of England, from the Earliest Period to the YEAR 1803, at 173 (1966) (emphasis supplied).

${ }^{166}$ A.B. KeITH, supra note 125 , at $9-10$.

${ }^{167} I d .381-82$. 
the presumption was that while in a conquered land the arbitrary power might be presumed to rest in the king, in settled lands, where perhaps the king had not so strong a claim to sole jurisdiction, it must rest in Parliament. The assumption, obviously, is that somewhere that external arbitrary power must be; the only question is its division between the king and Parliament. That, while a perfectly comprehensible (if tragically shortsighted) position for Mansfield, is startling in a twentieth-century commentator. The king's absolute power over Englishmen in a conquered territory-their rightlessness-was nothing more than a consequence of mechanical jurisprudence, wanting only a bit of imagination to set it right. What is there to explain the rightlessness of Englishmen in a settled territory, except the assumption of rightlessness in all Englishmen but those in the realm?

That was exactly Mansfield's assumption-and, as I have said, I find it easily comprehensible, if not particularly admirable. But I must confess to being baffled by Keith, who can say, first, that Parliament could of course do as it would in the colonies and, second, that the law held that the king was absolute in a conquered territory "only if he refrained from granting to his subjects the boon of English law."168 Wherein the "boon," I fail to see-as, of course, did the American colonists, and the Irish before and after them. Or, if it is, and is intended to be, a "boon," then must not one see what Coke saw, and be troubled as Coke was?

\section{Conclusion}

\section{A. Coke Reconsidered}

What do we suppose Edward Coke would have made of all this? I do not pretend to know "the" answer, or even to have done more in this Article than to hint at the issues, which are many and vexing. But it is clear that our informed guesses as to Coke must depend in part on whether we believe that Coke meant what he seems, prima facie, to be saying in Bonham's Case. If he was asserting no more than a rule of construction, then that is an end of it; if he meant that a common law court would in certain circumstances control an act of Parliament and ad-

${ }^{168} I d .10$. 
judge it to be utterly void, then we have a beginning. It is the assumption that Coke intended only to lay down a rule of construction which I would protest, and I take it some recent scholarship shows healthy signs of departure from this onceorthodoxy. ${ }^{169}$ Obviously, extensive support for this position cannot be indulged here and now. I will say, however, that those who think Coke was not, in Bonham's Case, asserting the duty of the court to declare acts void, should turn to the apparently never-read last pages of his report of the case. ${ }^{170}$ There Coke sets forth at length and with care the procedure to be followed in the future by the College of Physicians. It might be headed "Rules for Avoiding Being a Judge in your own Cause and Other Wise Precautions." This extraordinary exercise is surely best (if not only) explained on this theory: that Coke did mean that a statute making one a judge in one's own cause would be void and must be so declared by a court faced, unavoidably, with the issue; that he assumed the desirability of avoiding such judicial action; and that he was, therefore, trying to ensure that the issue would not arise.

Even accepting the broader interpretation of Coke's dictum in Bonham's Case, we can of course only speculate on whether the situation which is our present concern would strike an Edward Coke projected into the mid-eighteenth century as appropriate for the application of that dictum. The possibilities are obvious; it has been my purpose only to take a new look at the bearing of Calvin's Case on this point. As hitherto read, Calvin's Case would suggest strong and early attachment to parliamentary supremacy on Coke's part and would therefore tend to lead one to the narrower (statutory construction) interpretation of Bonham's Case. Read as I believe it should be, Calvin's Case suggests instead a strong attachment on Coke's part only to principled limitation, and thus tends to support the broader (higher law) interpretation of Bonham's Case. So much for the general bearing of Calvin's Case on Bonham's Case. More specifically, if we see that there really is no reason to think that Coke was anxious to preserve the power of the English Parliament over the dominions, then we might the more easily think that he would be favorably

${ }^{169}$ See Goebel, supra note 63, at 93 ("From Coke's language it was clearly to be inferred that a judicial declaration of nullity was anticipated as proper."); Gray, Bonham's Case Reviewed, 116 Proc. Am. Phil. Soc. 35 (1972). But see 1 B. BaIlyn, supra note 31, at 412; authorities cited at note 66 supra.

${ }_{170} 8$ Co. Rep. 107, 120-21, 77 Eng. Rep. $638,657-58$ (K.B. 1607). 
inclined toward application of the dictum-or the spirit of the dictum-in Bonham's Case to the American controversy.

Moreover, our investigation has suggested that Coke's attitude thus appearing in Calvin's Case-his sense of the anomaly of English parliamentary power in dominions having their own representative institutions-remained with him through the years from Bonham's Case (and Calvin's) to the Institutes. This, again, must presumably have some bearing on the problem presented by certain passages in the Institutes that have seemed to many to signal a retreat from Bonham's Case. Whatever Coke thought in 1610, the argument runs, at the end of his career he was a firm believer in parliamentary supremacy. Thus he wrote in the Institutes: "Of the power and jurisdiction of the parliament, for making the laws in proceeding by bill, it is so transcendent and absolute, as it cannot be confined either for causes or persons within any bounds."171 For all the exegetical effort expended on these words, we are far from an agreed-upon assessment of their meaning or intent, much less their implications for the colonies. We do not, for example, know whether to think of Coke as the now eager advocate of parliamentary supremacy in more or less its present form or the reluctant conceder of final authority to the High Court of Parliament. ${ }^{172}$ I suggest merely that it cannot be irrelevant that throughout his career-late as early-Coke seemed anything but eager to see the exercise of authority by the English Parliament over a dominion not sending representatives thereto. The passage quoted, however broadly interpreted, meant no more than that Parliament had "transcendent and absolute" power and jurisdiction where it had power and jurisdiction-not over all the king's subjects-not, surely, in Scotland. And Scotland was, we are told, the colonists' constitutional ideal. Was Ireland their constitutional fate? Coke urged in the Institutes that, as to Ireland, representatives be summoned when the English Parliament proposed to act in a matter concerning that kingdom. America's position surely ruled out the possibility of representatives at Westminster. Would Coke then have concluded that the English Parliament had "power and jurisdiction"--therefore "transcendent and absolute" power and

${ }^{171} \mathrm{E}$. CokE, supra note 103 , at 36.

172 The latter is Mcllwain's interpretation, C. McIlwain, The High Court of Parliament and Its Supremacy (1910), concurred in by J. Gough, supra note 61, at $41-43$. 
jurisdiction-in America as in Ireland, or not, as in Scotland? At a minimum, I think we must wonder whether the colonists did reach conclusions which would have been alien to the thinking of Edward Coke and whether fidelity to Coke must, in truth, have led one to miss the Revolution.

\section{B. McIlwain Revisited}

We may now, in conclusion, turn to the touch of rightness in McIlwain's thesis. If I am right in supposing that before the Interregnum the only power over the dominions was the king's-that is, that parliamentary power was in essence conciliar - then we can find that touch of rightness. By 1774 the conciliar theory was no more; we have remarked the shift. ${ }^{173}$ And that shift deprived the colonists of whatever legal advantage they could take of the historically sound conciliar theory-of the chance to argue that with the reduction of the king's power and the increase of the representative dimension of the imperial constitution in law as in fact, anomaly had become impossible internal contradiction ("repugnance"?). And the shift in theory was indeed that very "disastrous political subordination to the Englishmen of 'this Nation' and to the 'Supreme Authority' of their Parliament, of all other Englishmen outside the realm in dominions formerly belonging to the King" which McIlwain saw, truly, first expressed in the Commonwealth Act of 1649. Since the shift in theory involved the obliteration of every trace of principled limitation from law and its relegation to the precarious plane of practice-later dubbed convention-it is quite right to say that once the issue was "cast in a legal mould" hope of resolution was pretty much lost. But the reason for this was not that Parliament had legislated for the dominions continously from the time when the memory of man runneth not-though it had. The destruction of that hope was a thing of the post-settlement period, and it was indeed first expressed in the Commonwealth Act of 1649.

De jure, of course, the shift does not belong to the Interregnum. Goebel, like many others, pins it to the Glorious Revolution. ${ }^{174}$ I am not at all certain that I agree. I am inclined to believe that the doctrine of parliamentary omnipotence was (1) necessary to the total obliteration of the colonists' hopes, (2) a 
development of the mid-eighteenth century, and (3) not reasonably foreseeable in 1689. Thus, for one thing, I join McIlwain in saying: "And it is certainly a strange assumption that the colonists in proclaiming William and Mary must inevitably have accepted and for all time all the unforeseen constitutional consequences that an oligarchical parliament might later choose to deduce from the transactions of 1688 and 1689."175 And for another, I suggest that if the end to all hope for the Americans came as late as I suspect it did, we might well have worked an agreement on colonial immunity from parliamentary power into "our" constitution without any fear that we had simply neglected to call a Revolution a revolution.

${ }^{175}$ C. McIllwain, supra note 4 , at 14-15. 